\title{
Locating to 'Erotica' Themes in to Translation and Transcription of Palm-Leaf: Reading an Un-Known Odia 'Kāma-sūtra'
}

\author{
Santosh Kumar Mallik \\ Assistant Professor in Dept. of History, Nayagarh Autonomous College (Utkal University), \\ Nayagarh, Odisha, India. Email: santoshkumarmallik@gmail.com \\ Received July 29, 2017; Revised September 02, 2017; Accepted September 15, 2017; Published September $20,2017$.
}

\begin{abstract}
s
This paper is entitled "Locating to 'Erotica' Themes in to Translation and Transcription of Palm-Leaf: Reading an Un-Known Odia 'Käma-sūtra". The main aim of this essay is to see how translation intercedes in the emplacement of cultures. For my purpose, I shall take up an illustrated poetical composition of unknown/unpublished palm-leaf manuscript called 'Chauṣhathi-Rati Bandha' by the Odia poet Gopala Bhanja, and his translations/adaptations in particular that text regularized by a set of erotica theme and factors like erotica-literature in the form of vernacular or local "Kamasutra".
\end{abstract}

Keywords: Erotic Fantasy, Illustrated Manuscript, Odia Literature, Medieval Kings Court, Courtly Culture, Production of Pleasure product (Erotic Illustrated Manuscript).

The main aim of this essay is to see how translation intercedes in the emplacement of cultures. For my purpose, I shall take up an illustrated poetical composition of unknown/unpublished palm-leaf manuscript called 'Chaușhațhi-Rati Bandha' by the Odia poet Gopala Bhanja, generally acknowledged as one of the makers of medieval Odia literature. I shall endeavor to explain that Gopala Bhanja's long illustrated-poem was patterned after composition of Vātsyāyana's Kāmasūtra, and some relevant later works of other vernacular Kāma-sūtras. However, my curiosity is not so much with retracing conventions of similarities and differences between the two texts so as to agree on the question of what George Steiner pertinently calls 'fidelity' and 'betrayal'- the traditional objective of translation study. Instead, I shall treat the translated text 'Chaușhațhi-Rati Bandha' as a free and independent interpretation. I shall effort to confirm that Gopala Bhanja's translations/adaptations like 'Chaușhațhi-Rati Bandha's regularized by a set of erotica theme and factors like erotica-literature. In unambiguous stipulations, I hope to demonstrate that Gopala Bhanja in 'Chaușhathi-Rati Bandha's was not very hampered by the need to evoke the classical Indian heritage or to attempt poetical innovations through the use of Kamasutra of Vastyana's sources. As a medieval poet working in a specific erotica matrix, Gopala Bhanja, I argue, was engaged in the formation of a regional cultural identity through the subjects of ancient legacy, those are depicted in the temple art of Odisha in every nook and corner as well in Ritī-Yugìya poetical composition.

(c) AesthetixMS 2016. This Open Access article is published under a Creative Commons Attribution Non-Commercial 4.0 International License (http://creativecommons.org/licenses/by-nc/4.0/), which permits non-commercial re-use, distribution, and reproduction in any medium, provided the original work is properly cited. For citation use the DOI. For commercial re-use, please contact editor@rupkatha.com. 
To investigate the subject matter comprehensively we have to explore the available sources of palm-leaf records for the translation and transcription of the specific manuscript or colophon. In the context of Odisha and its palm-leaf tradition is very old age phenomenon; subsequently far the earliest evidence of a palm-leaf manuscript dates to CE 795, when the Chinese emperor Te-Tsang received as a token of homage an autographed manuscript of Avatamsakasutra addressed to him by king Subhakara ${ }^{\text {ii }}$ of $\mathrm{Wu}$-cha (Odisha). ${ }^{\text {iii }}$ Mainly the paper deals with the two part or sections one is deals the form, perspective and practice in the palm-leaf manuscript traditions. The second part of the paper is concentrated through the translation and critical interpretation.

\section{Form, Perspective and Practice:}

In this section, a fruitful discussion regarding the categorization of the sexual postures (ratibandha) in Odishan context are vividly done from sources derived from the Odia palm-leaf manuscript preserved in the manuscript section of Odisha State Museum. This work explores the regional terminology of the sexual postures (rati-bandha) as well as in its English equivalents for the better understanding. In this regard, manuscript section of Odisha State Museum provides relevant information from available illustrated palm leaf manuscript regarding erotic theme. Out of plenty manuscripts ${ }^{\text {iv }}$ available there, the erotic illustrated works like Gìta-Govindav (Ext. 166) of Jayadev, $12^{\text {th }}$ Century, is a classic treatise on the twinges of Radha in waiting for reunion with her eternal lover, Krishna. Radha's reveries as consort to Krishna are movingly narrated in verbal icons of sheer sensuous detail. This manuscript describes about the story of Radha and Krishna with the time of sting of Radha, who became keenly interested on Krishna's love, which one scribed and painted in Gìta-Govinda which one illustrated format and commentator by Dhananjaya. Whereas description of the sexual life of Krishna and Radha, the basic purpose of the privileged sexual behavior in the courtly tradition through the name of Hindu god and goddess. Because that time producing format of the any fine art product as well as literary activities also referenced the Hindu mythic individuals, those are merely active in the purpose of sexual behavior like produced of Gìta-Govinda. This manuscript is counting among the finest flowers of Odishan art as well as Indian context. The approach of the artists to the theme might vary, from grace and submissive reverence to the joyous celebration of love.

Another manuscript Ușhāvilāsa $a^{v i}$ (Ext. 319), a $16^{\text {th }}$ Century epic, has been amongst the most inspiring pictorial love story of Usha and Aniruddha. Rainbows of passion and burning desire in its rawness power this sachitra pothi. The poem has rich visual imagery and the act of painting is an integral part of its narrative. The protagonists Usha and Aniruddha are presented as ideal medieval nayaka and nayika; the former is both dhira (gentle, patient) and udatta (impassioned) and the latter is mugdha (the charmed one, the tranced), She is not only a paragon of beauty; the elegance and charm of her physical features are described through a number of conventional flower metaphors; she is also well-versed in the arts including the game of dice. Aniruddha is a great hero, the charming prince who is extremely handsome and the true inheritor of the clan of the Yadus. Their love and eventual marriage is in the pattern of Yayati marrying Sharmistha and Bhima marrying Hidimba both from the clan of demons.

Amarusatakam vii (Ext. 388) of Amaru (or Amaruka) is a stand-alone as perhaps the most vivid graphic representation of la amorthat celebrates the ideal conjugal courtship sans inhibition. It depicts the joy of love or Sambhog Sringar in all its richness and variety. If Vatsyayana's Kamasutra is the most famous theoretical and scientific treatise on love, Amarushataka is its most beautiful and graphic exemplification in the poetic form. 
Kumuda-Kānta Chautiśha ${ }^{\text {viii }}$ (Ext. 139) is a masterpiece on love in its entire splendour between Radha and Krishna. Each of the 34 stanzas is a tribute to a love-lock that pans deep and across the floors of abiding passion. The manuscript depicts the attractive colour illustrations. The manuscript depicts the colour illustrations. Some erotic figures of Radha and Krishna have been decorated here. Krishna is black and Radha is white as presented in the manuscript.

Rasika Harāvalix (Ext. 40) of Kabi Samrat Upendra Bhanja, 18th Century, is an erotic delight. Rarer would be a source which depicted a woman (the title heroine) not only in bodily detail but also the voluptuousness behind strokes of desire, dream, fantasy, fear, both pre-puberty and post. The poet seems to have given importance to Bipralambha Sringar in this long poem. This is one of the important Kavyas of the famous poet Kavi Samrat Upendra Bhanja. This Kavya is completely imaginary in nature for which the theme of the Kavya is consisting pictures of different lilas, roaming of garden, exchange of letters of the nayaka and nayika.

In the above mentioned and elaborated issues are the main content of those manuscript and some other available manuscript such as Bidagdha Mādhava ${ }^{x}$ (Ext. 310), Pañcha-sāyaka ${ }^{x i}$ (Ext. 168) and Chaușhațhi-Rati Bandha $a^{x i i}$ (Ext. 329 (Colour), 342 (Black \& White) based on the local Kāma-sūtra type work.

These mainly cover the time frame from $9^{\text {th }}$ century onwards to $18^{\text {th }}$ century $(\mathrm{CE})$. But the most interesting thing is that as the manuscripts are fragile in nature, it is very much difficult for one to conserve the original copy for so many years. Hence the best method for their survival or their higher longevity is to re-write and re-scribe the original manuscripts or make a digital document, which could later be used as the original texts. There is much possibility that all those aforesaid manuscripts discussed above might have gone through these phases. Hence it would be superficial and difficult enough to follow the time frames of such documents. So by re-writing or re-scribing the manuscripts several times in several periods by various authors, there is a gradual fluctuation in the exact date and time frame. For instance, the time frame of Amarusatakam (Ext. 388) belongs to $9^{\text {th }} \mathrm{CE}$, but the available manuscript derived from the Odisha State Museum dates back to $17^{\text {th }}$ CE. Adhering to these above principles, the "Bhāgavata Turigi”, "Gādi-Brahama Pìtha", "purāna-paṇ̣̂a pothi-ghara" and "țhākura-ghara" (assembles of the Dharma-Śhāstra form of palmleaf manuscript and (kula-devatā/devī) deities) the oldest existing manuscript of Odisha has been preserved till date in the nooks and corners of Odisha. The very purposes of such texts are to stimulate the idea of Silpa-śāstra, Mūrti-gaḍhaṇa, black magic, Chaṇḍi-sādhanā, Tāntrik-sādhana, alchemy, ancient Odia Padyāvalīs and the other spheres.

When the traditional paintings are considered with the angle of vision of the devoted artist, two things come to our mind. One is the expression of one's emotion and the other is the skill of decorative pattern. As the traditional painters are ignorant of modern scientific perspective, they begin the painting from the life movement and emotion. ${ }^{\text {xii }}$ This is the rhythmic line of painting. At first they place the main character in the centre, and then they proceed to arrange the secondary characters according to the ornamental pattern. There is the exact expression of gesture, emotion, balance, experience etc., in these paintings. The illustrated palm leaf manuscripts of Odisha are a special character of advancement of Kāvya as well as representation of the paintings. The illustrations on a small long format of palm leaf with the help of iron stylus are the work of highly gifted Odia artists. These speak of their tremendous patience and artistic ability. For instance, there are so many erotic literatures produced in Odia language, which enriched the tradition of Vātsyāyana's work as an available resource in vernacular language for common masses. 
In this paper, the Odia terminology for sexual postures shows mainly concentration of the work of above mentioned poet. The stylistic ornate poetry in Odia is the direct product of Jaydeva's Gìta-Govinda. Form it arose the ornate chautiśhā, which slowly evolved and expanded into ornate Kāvyas. The decadent Sanskrit classics of the $9^{\text {th }}-10^{\text {th }}$ centuries also had a good share in this evolution. Jayadeva's popular lyrical drama dealt on two poetic ideals before aspirants to literary fame, which is, firstly poetry should and could be sung and secondly, human sexual behaviour is the only and the most fecund source on earth for poetic material. ${ }^{\text {xiv }}$ It is difficult to say with which particular writer started this composite fashion in Odia poetry. As has been said before, experimental beginnings had been successfully undertaken by some of the unambiguous and unpretentious Chautiśhä-makers. ${ }^{\mathrm{xv}}$ They added the fire of music to versification. They also tried to impart fine rhythmic effect to verse by sheer arrangement of letters and word, without caring much for clarity or precision of sense. ${ }^{\text {xvi }}$ The ornate Kāvyas and Mahākāvyas or the ChitraKāvyas as the connecting thread. Odia translations of Gīta-Govinda, essentially a lad and a lass's story, so abundant in Odisha, might also have shown the way for this type of poetry. .vii $^{-}$

Within certain limits, the ornate poetry produces an excellent aesthetic impression. The clever manipulation of sound and sense does provide an elegant and acceptable intellectual pleasure. ${ }^{\text {xiii }}$ This type of poetry may be called linguistic jewellery; it tries to create the maximum aesthetic effects out of the raw materials of the common words in a language ${ }^{\text {xix }}$ If poetry may be taken as craftsmanship in words, so far as its physical aspect is concerned, then the enormous mass of medieval ornate poetry, not only in Odia but in other Indian languages, is not to be rejected outright, but may be accepted as possessing a sound literary right to existence. ${ }^{\mathrm{xx}}$ The trouble, however, is that this genre has abused this right by going to morbid, senseless excesses and by confusing a mere style with the very art of poetry itself. ${ }^{\text {xi }}$ Odia ornate poetry of this period displays usual virtues as well as the vices of this style in profusion, the latter far in excess of the former. ${ }^{\text {xxii }}$ The Chautiśha-makers belonged mostly to the northern districts of Odisha. But strangely enough, the great protagonists of Odia ornate poetry hail mostly from South Odisha, the Bhañjas of the ruling family of the long defunct principality of Ghumusara in South Odisha standing as symbolic of the entire school for all these centuries. ${ }^{\text {xxiii }}$

The Bhañjas are the best known and most historic ruling class of Odisha. It has been rightly said by the historian R. D. Bannerjee that while the ancestors of the famous Rājpūt clans were still nomads with painted bodies in the central Asian steppes, these Bhañjas were ruling over prosperous territories in eastern India. ${ }^{\text {xiv }}$ Even now they are to be found all over Odisha. But the Bhañjas of Mayurbhanja and Ghumusara have become parts of the national life of Odias, by their significant contributions to and patronage of arts and literature. ${ }^{\mathrm{xx}}$ In the midst of murders, frauds, intrigues and unspeakable immoralities, the rulings Bhañjas of Ghumusar kept up a living tradition of literary culture in the family. Upendra Bhanja is merely the culmination of this tradition. Original in nothing, he just fulfils in a grandiloquent manner, the trends that had been started and carried on by his uncle and grandfather and same thing also happened with Gopala Bhanja of Mayurbhanaj. Having eclipsed all else in the filed by his success in this particular line, in a superb manner, Gopala Bhanja and Upendra Bhanja now stands as the archetype of ornate poetry in Odisha, casting his shadow down to modern times.

\section{Translation and Critical Interpretation:}

The availability of dilapidated folios of Chaușhațhi-Rati Bandha mention about the sexual postures very rhythmically and there is some line drawing about the postures which seem like other earlier line drawing manuscripts. These folios describe the postures of sexual union but 
some letters are not identified. These description on various sexual postures are more or less similar with the Kâma-sūtra but in the Odia language. The styles of writing, the trend of Ritiyuga, annex of feudal cum courtly culture mostly created poetries are basically influenced by the ornamental language. These types of literary activities deeply indulged with the influences of Sanskrit language which are reflected in the course of time. It can't be ignored that the development of 'Rìti-yugīya Oḍiä' literature got its momentum through the king and courtly patronage, feudal chiefs and their courtly members. Therefore, the writing styles are more or less showing the influence of Sanskirt language in each and every works of Upendra Bhanja. From the linguistic point of view also there are certain similarities between Odia and Sanskrit language and is a common trait found in the Indo-Aryan group of languages. Although Gopala Bhanja several times uses the Sanskrit terminology for the sexual postures and some are in Odia language as per his convince to writing of the poetry and it is mainly reflected in the work of Chaușhațhi-Rati Bandha.

This section will discuss about the sexual postures which are depicted in the ChaușhathiRati Bandha, composed in Odia language by Gopala Bhanja of Mayurbhanaj district in Odisha, who belonged to the Bhañja dynasty. Some folios are in dilapidated condition and this palm-leaf manuscript is preserved at the Odisha State Museum in Bhubaneswar. Chaușhațhi-Rati Bandha manuscript is available in two types, one is the colour in painted format and another one is only line drawing with stylus (Catalogue No. Ext.342). In this paper the line drawing erotic manuscript is choosen because it's earlier than the colour manuscript, its date belongs to $16^{\text {th }}$ century AD and this one is not yet published.

Biparita Bandha (Alternate Posture): In this posture the male keep both of the leg of his partner on his shoulder and performs sexual intercourse by kneeling down her. It is called Biparìta Bandha. (Verse: 1)

Ekapada Bandha (Single Leg Posture) (Fig.1 \& 22): The male pulls the left leg of the female towards his back side and pulls her other leg towards his chest portion and perform sexual intercourse by tightly holding the hip and neck; it is called ekapada bandha. (Verse: 2)

Malla Bandha (Wrestling Posture): The female sits over the male, holds both of his thighs with the hands and copulates by facing downwards just like a deer; it is called as Malla Bandha. In this posture the males holds the female in his able hand for which sexual intercourse becomes easier. If the male does the same with the female; it will be called as Biparita Malla Bandha (Alternate Wrestling Posture). (Verse: 3 )

Bhadrā Āsana Bandaha (Gentle Seated Copulation): The female sits gently on the thigh of her partner and perform slight sexual congregation without being wild is called Bhadrā Āsana Bandaha. In this posture there occurs limited sambhoga but full of gracious love of mithuna. (Verse: 4)

Susama Bandha (Unproblematic Posture) (Fig.2): The male keeps both of the leg of the female in his right shoulder and penetrates his penis into the vagina and holds the breasts in the right hand and holds the hips/hip in his left hand and perform sex. It is called Susama Bandha. (Verse: 7)

Kūrma Bandha (Tortoise Posture) ): The male and the female both sit in frontal position holding the neck portion; the female keeps her foot on the thigh of the male and spreads her leg behind and connects her vagina with the penis holding the neck portion tightly and copulate. This is called Kūrma Bandha. (Verse: 8) 
Karkana Bandha (Anklet Posture) (Fig.3): The male and female stand together holding or connecting one of their hands and legs respectively and performs sex in the embracing mode; it is called Karkaṇa Bandha. (Verse: 9)

Käka-Rati Bandha (Scissors Posture) (Fig.4 \& 20): The male sits spreading his legs erectly and the female keeps her left leg in between the two thighs of the males and connect her vagina with the penis and keeps her other leg just near the right leg of the male which seems like scissors. Both sit in frontal position facing each other and copulate. It is called Kāka-Rati Bandha. (Verse: 10)

Jarighā Āsana Bandha (Thigh Posture): the male sits on the thigh portion of the female and presses both of her breasts. Very often the male pulls down the thighs of the female towards him and perform sexual intercourse. This is called Jarigha Âsana Bandha. (Verse: 22)

Urdha Pãda Bandha (Uplifting Posture) (Fig.5): The male uplifts both of her foots, keeps that in front of him and performs sexual intercourse, holding the foot tightly. It is called Urdha Pāda Bandha. With this one can achieve pleasure and lead a happy conjugal life. (Verse: 23)

Bakra Bandha (Curve Posture) (Fig.6): The male opens widely both of his thighs and the female sits over the penis of her partner; both of them sits front to front facing each other; that means looking opposite direction. It looks like bending and it is called as Bakra Bandha. (Verse: 24)

Mṛugamata Bandha (Standing Deer Posture): (Fig.7): Here the female just bents like a deer on the bed and the male holds her waist in behind and performs sex. This copulation is performed standing like the animals. As the female bents like a deer; this posture is known as Mrugamata Bandha. (Verse: 47)

Makșharā or Kaḍa Bandha (Tangential Sleeping Posture): The female sleeps straight on the bed and the male sleeps along side with the female stretching his leg, than holds the female with his left hand and the female also holds the man with her right hand and the copulation is performed. It is called Makshara Bandha. (Verse: 48)

Rati-Bikrama Bandha (Violent Copulation) (Fig.8 \& 19): The male uplifts both of legs of his partner and try to perform sexual congregation violently. In this posture if the back side of the female rests on the bed or a pillow; than the copulation will be easier; as result the female stands just like a boat and sexual copulation will be much easier. (Verse: 49)

Nișţura-Jhulä Bandha (Cruel Hanging Posture) (Fig.9): The male instructs the female to hold her two legs with her hand in a semi-circular posture. The female sits over the lap of the male; the male copulates with her pulling the breasts towards him. That is called Nisthura-Jhula Bandha. (Verse: 50)

Chhanda Bandha (Criss-cross/Knot Posture): By keeping both of the foot of the female on his head; the male pulls the female towards him holding her waist portion and copulation is performed. It is very pleasurable to perform sex from the back side of the female. It seems like a criss-cross structure; hence it is called as the Chhanda Bandha. (Verse: 53)

Padmāsana Bandha (Lotus Seated Posture) (Fig.10): in this posture, the male sits in the Padmāsana and the female sits on his lap. Both of them look towards in same direction; keep both of their hands like a lotus and perform sexual congregation. Hence it is called Padmāsana Bandha. (Verse: 54)

Puruṣha-Janghāsana Bandha (Male Thigh Seated Posture): The female sleeps on the bed straightly; the male keeps one of his leg towards the backside of the female, and other on the bed 
and copulates with the female. It is called surati or proper intercourse. But this bond has not been given by any name. So, it should be called Puruṣha-Jarighāsana Bandha. (Verse: 55)

Chakrābhāba Bandha (Circling Mode Posture): The male penetrates his linga in the female sexual organ; who is sitting in his laps and both are seen in an embracing position. Both of their faces should be in one direction; that means the back portion of the female touches with frontal portion of the male and they make sexual intercourse. (Verse: 56 )

$\bar{A}$ śhirta Bandha (Shelter or Leaning Posture): In this posture, the male keeps his body between both the thigh portions of the female and copulates. During this period one of her thigh rests on the bed and another thigh keeps over the thigh of the male and copulates. The male pull the breasts of his beloved towards him; both of them copulate with each other sheltering among themselves; which is popularly known as āśhirta-bandha. (Verse: 57)

Subhajākruti Bandha or Surjakruti Bandha (Auspicious Seating Posture): First the male holds both of the thighs of the female; then he keeps her both breasts with proper care and copulates seating front to front is known as Subhajākruti Bandha. (Verse: ${ }^{8}$ )

Ālingana Ubhā (Thiā) Pāda-chhanda Bandha (Embracing Standing Posture) (Fig.11 \& 17): Both the male and female embrace each other standing front to front and interconnecting one of her feet and one of the hands. It is called Ālingana Ubhā (Thiā) Pāda-chhanda Bandha. (Verse: 71)

Drüdha Bandha (Firm Posture): The female sits on the thigh of the male and he kisses the breasts and the chin of the female, holding tightly both of them copulates. As a result; both of them perform sex tightly and is called Drüdha Bandha. (Verse: 72)

Urdha-mukha Bandha (Upper facing Copulation): By keeping his face and body in straight position, looking upward, if he penetrates the linga into the yoni of his female partner; it will be called as Urdha-mukha Bandha. (Verse: 73)

Kuchābhàba Bandha (Breast Resting Copulation): The female sits on the thigh portion of the make in frontal position, pulls her neck portion in his left hand and embraces. The female entangles her leg across the waist portion of her partner and performs sex. This is called Kuchäbhäba Bandha and this type should be performed from below or backside of women. (Verse: 74)

Bikāra or Swastikāsana Bandha (Multiple Seated Copulation) (Fig.12): The male sits in the Padamāsana and the female Swastikāsana; that means she spreads both of her thighs to an optimum level and keeps the hands on the neck portion of the male and sits in front of the male looking in one direction, kissing each other and perform sex. This is called bikara-bandha or Swastikāsana Bandha. (Verse: 75)

Trikona Bandha (Triangle type Posture): Here the female keeps her left leg straight to the bed and pulls her rights leg towards her breast portion; the male also does the same and copulates. It seems like a triangle. In this posture both of them embraces their leg and perform sex. (Verse: 77)

Mekhala Bandha (Waist Posture) (Fig.13 \& 18): The male sits in fronts of the female and pulls the right leg of his partner towards his face. The female keeps her right feet in front of her face and embraces the legs. The male performs sex by holding the waist of his female partner; it is called mekhalä bandha and this one also similar with Trikona Bandha types. (Verse: 78)

Ghana Bandha (Deeply Indulged/ Creeper type Copulation): The male stands formally and pulls both of the legs of the female towards him, spreads it and perform sex. The female holds tightly the wall or the bed. Very often the female keeps both of her hand in the neck portion of 
the male like creeper or garland which helps to perform sex easily. This is called Ghana-bandha. (Verse: 79)

Kumuda Bandha (Full Blown Louts Posture) (Fig.14): The female holds the foot of the male in both of her hand and keeps her face just near the foot of the male. She keeps both of her legs on the shoulder of the male. The male presses the breasts of the female, and in this period copulation starts as their genital organs come closer. This is called Kumuda Bandha, like full blown lotus the vagina becomes wide spread and hence it will be easier enough to copulate. (Verse: 8o)

Bakra Bandha (Curvature Posture): The female is bent just like the incipient bamboo wood and made circular and perform sex from the below portion holding her waist portion. It is called Bakra Bandha. (Verse: 81)

Adhomukha Bandha (Semi-circular Posture) (Fig.15): The female bends by kneeling down and the male performs sex from the back side and this posture is called Adhomukha Bandha. (Verse: 82)

Samukha-bandhe Bandha (Frontal Posture) (Fig.16 \& 20): The female sits on the lap of the male; her hands twist on the neck portion of the male and by kissing their face each other; they perform sex. It is called Samukha-bandhe bandha. The scriber and writer of the Manuscript Gopala Bhanja mention all the sixty four postures and its utility by the later phase. He has described these postures or posture and its utility for all round development of moral character. (Verse: 85 )

\section{Text (Religious/Sac-Religious) Influenced Poetry and other (Temple) Arts (?):}

Yes, as per the rules some text are written in latter period cause of its significance and these texts are influencing directly or indirectly in earlier literature; it may be literature form like poetry, prose, epic, canons or talk about iconography or temple architecture; which is clearly visible in the context of Odidishan erotic literature and temple art. The eroticism in the temple art of Odisha is an issue of Odia Shilpa-texts such as 'Canons of Orissan Temple Architecture', 'Shilpa Prakasha', and 'Silparatnakosa' and some other Odia-Tantrik unpublished manuscript also available to proof the arise questions, such text are Angirasakalpa, Uddisatantra, Sharadasharadarjina Paddhati, Tantra Chintamani, Yantra Chintamani, Dugausatova, Bhubaneswari Pujapallavi, Durgausatova Chandirika, Durugayajanadipika, Tarenikula Suddhatarangini, Tarachhanatarngini, Gynavalli Tantra, Shiarachhana Paddhati, Shyamarachhan Paddhati, Banaduruga Puja, Shree Vidyapati Paddhati, Ugratara Padhhati, and Bhubanswaripraksha.

Let's see how the texts influence over literature and temple art; so the context temple of eroticism will not be a concept to be ashamed of. The eroticism in Odishan art is its materialistic manifestation depends on the personal thought of an individual which varies from person to person. It is philosophical in nature and thought. In other words the philosophy that has been flourished in the Indian tradition on the concept of eroticism from the Vedic period onwards has a deeper value. If the unions of male and female are taken in the positive interpretation then one can attain the highest form of liberation i.e., the moksha. Sexual urge in the extreme pleasure of a life, where the human being get their ultimate wisdom. The eroticism of Odishan temple may be noticed in various angles. It should be remembered that one of the interpretation is enough and none of them are obsolete in nature. 
The first interpretation comes under the ambit of procreation. The sun is the chief source for the creation, the sun ray gives life to the tree, fragrances and colour to the flower and fills the juice of a fruit. What is it? This is nothing but a mere conglomeration of two most pure lives of nature, the male and the female. Hence, the union scenes of male and female engraved in the temple walls is not vulgar in nature.

Second in the Indian tradition temple is compared with metaphysical body. As the temple contains a god likewise the metaphysical body possesses a soul. According to the Brihadaranyaka Upanishada, "the amorous couple embracing with each other with a pure intention of love in their heart and mind which is really praiseworthy. These should not be condemned or tarnished."

In another outlook, the outer frame and the broad vision of art is the universe itself. He who never led a worldly life could not know the essence of creation and it's amazing behaviour. If someone is leading a household life then he or she gets the extreme pleasure of the universe being involved with it. In the twenty eight verse of Brahampuran, Konark has been mentioned as the cradle of 'Kama' and 'Paragati' or salvation (deliverance). So Konark is not only a giant temple of Odishan architecture but it is the symbol of medium of the worldly creatures to lead a better household life in the $9^{\text {th }}-10^{\text {th }}$ century. It is the intermediary body between materialism and spiritualism. Here it would clearly be stated that the posture and attitudes of tantrik worship in Odisha might enter meagerly into the lifestyle of Odia people, but the role of tantricism is negligible to witness the entire architectural and sculptural philosophy.

The philosophical understanding behind the erotic art of Odishan temples are being studied according to scriptural ideas. In Skandapurana it has been stated that the eroticism in temple saves it from the thunderbolt. Again in Bhagabatpurana it has been described that the Brahmahatya culprit Indra distributed its entire sin among the land, water, tree and female. So, the erotic female figure will not damage by atrocities of Indra's thunderbolt.

In Brihatsamhita, Varahamihira has vividly described that the divine birds, trees, creepers and mithuna figures are the ornaments being engraved in the temple wall. Much discussion is being made having possibly of Jaina and Saiva influence in the temple art of Khajuraho. But no such discussions are conducted in regards of Odishan temples. The sole cause is that the proportionate imposition of mithuna and maithuna figures in the temple. The erotic arts are well balanced with other artistic design like tree, bird's animal and religious figure, etc.

The art of Konark is not merely a medium of decoration or ornamentation rather it is the unique artistic framework of an Odia sculptor, where the 'body' or 'health' of a female or male becomes the chief ingredients. In the words of Ananda K. Coomarswamy "how art becomes the technical part of artistic manifestation Konark in the proof of it in the entire universe."

According to the Bayachakada; each and every motifs has a utilitarian purpose. Though the alasakanya looking beautiful yet those serve on the bharavhaka in the sikhara. Just like the kalasa and simha are also posses their utility. There is no vulgarism in the temple art of Odisha. There is no obscenity in it. It exhibits the holy union of the amorous couple, just like all the sculptures are the festivity of life. The temple art of Odisha reflects the socio-economic-cultural life style of the people. This temple art gives a new language of liberation by juxtaposing nirvana with the sexual satisfaction. Above discussed information are suggesting that the influence of text towards the fine art categorizes, like art, literature or temple art and architecture. 


\section{Observations and Discussions:}

The various sexual postures in the above mentioned unpublished manuscript and in the other discussed erotic manuscript; the erotic postures are seemed to be similar. Of course there is some difference in its nomenclature and for that; often this would from somehow indistinguishable. If this is minutely studied all those sexual postures are not varied in nature in the true sense of the term. Hence the comparative study Pañcha-sāyaka and Chaūṣhațhi-Rati Bandha (line drawing) discussed in this section proves to be a relevant research oriented manuscript. So in this context of present work, both of the manuscripts assure importance and their antecedents are represented through the erotic visual imagery in the earlier times. The postures described in the Pañcha-sāyaka resembles with the pre-sexual play and sexual postures, several contents, other rules and regulation of the Kāma-sūtra. But the painted or illustrated Chaūṣhați-Rati Bandha differs variedly with the line drawing manuscript. The interpretation of the line drawing manuscripts Chaūșhațhi-Rati Bandha and the Pañcha-sāyaka are fruitful enough to be studied. The erotic sculptures depicted in the temple wall resemble with the erotic line drawings and illustrated manuscript and typologies described in the manuscripts. It would not be justified to say that the Pañcha-sāyaka and Chaūșhațhi-Rati Bandha only narrate on sexual postures. In these manuscripts, there is vivid description on dos and don'ts before copulation; just like the Vātsyāyana's Kāma-sūtra. Various words also seem similar with the Kāma-sūtra. Both of the manuscript (Chitra Kāvyāvalī) comes under the orbit of Rìti Yuga literature of the contemporary society. Hence the Rìti Yuga does not only exhibit about the Rati-Kāmadeva, Rādhā-Kṛiṣna, UșhāAnirudha or their sensual sexual activities or love and affection; but it shows the feudal audacity, ostentatious nature of status and rigid fundamentalism in its literatures. It would be unfair to say that this tradition was only visible in the contemporary literature; rather it was highly reflected in the social strata. It might be also possible factor that the erotic sculptures engraved in the Odishan temple served as an agency to appear later in the manuscript tradition of Kāvya literature in the form of line drawing and colour painting.

The sensuous literatures and its narration starts from the period of Charyāa $\bar{a} \bar{t} i k \bar{a}\left(7^{\text {th }}-9^{\text {th }}\right.$ C AD); but this period witness the growth and development of Buddhism and Sunyabāda taking the traditional subjects or themes as the motto of life. Again its relevance and utility would to the development of contemporary literatures are noteworthy. The period in which man wanted to tie up with religion and society or became victimized by the Brahmanical supremacy; at that time; the Charyā-gitikā holds the responsibility to keep the society and religion in balanced way. But the literature after the period of Charyā-gìtikā, mainly centred on Vaișhnavism, the Rādah and Kṛișna's love and affection, the Rādhā-Bhāba towards to Jagannātha or Vaisnavaite faith more regulated the literary activities of this period. The influence of Odia Jagannatha Dasa's work ${ }^{\text {xxvi }}$ and Bengali Chaitanya's Sahajiä Vaiṣnava idea led the society somehow to fall in the love for Kṛiṣna and Jagannātha. At the same time, they tried their level best to impoverish the notion of primitive sexual desire of human being diverting their attention to the Rādhä-Kṛiṣna. For that reason, the erotic consciousness developed in that period was imbued with religious thought which was described in the Bhāgavata of Jagannatha Dasa. The Bhāgavata mention about the "erotic fantasy" in the form of spiritual based happy family life or ideal family. ${ }^{\text {xvii }}$

It would be unfair for us to say that the Riti Yuga are nothing but the sexual sensuous literary thought, because it is the Ritti Yuga which readily condemned the Brahminical thought and went for their own creative writing; which was later on looked down upon by the society. The literature of Upendra Bhanja, Dina Krushan Das, Devdrulava Das, Bhupati Pandit, Avimanyu Samantasimahar and Brajanatah Bada Jena are dubiously distinct as erotic-sensuous literature. 
The controversy regarding Bhanja's work has been unpopular because the controversy started in 1893 \& $94 .{ }^{\text {xxviii }}$ After these issues the Bhanja's work was looked down upon by the then contemporary society, rather the later society also considered the writings as illogical and harmful to the society, thus not giving any importance and it resulted into no development of such genesis later. The middle class English educated gentleman, the influence of Christianity and the improved moral codes during imperial rule which was surely responsible for it silence.

However, the growth and development of sensuous literary creation being flourished during the Riti Yuga and this paper clearly described the various sexual postures from the above mentioned palm-leaf manuscript and provided details of the original line drawings and textual elaboration of above mentioned manuscript. The information extracted from those manuscripts is translated in order to understand the description of sexual postures.

\section{Acknowledgement}

The author is tremendously gratified to his PhD supervisor Prof. (Dr.) Y. S. Alone, Professor in School of Arts \& Aesthetics, JNU, New Delhi for his comments and insights that have been central in shaping his ideas and JNU Administration to allow me for publication of this paper from my part of $\mathrm{PhD}$ work. I am exceptionally appreciative to Dr. Bhagyalipi Malla, Superintendent Odisha State Archives and Former Curator Manuscript Section of Odisha State Museum, Bhubaneswar to allow me for use the particular Manuscript section and access the precious materials, and time to time discussion for my work. I am also indebted with Prof. (Dr). Sadsib Pradhan (Utkal University), Prof. Dr. Ravi Mohanty (Deccan College Pune) and Prof. (Dr) Sanjay Acharya (Utkal University), Dr. Iswar Parida (Asst. Prof. Haryana Centeral University) for their valuable comments, suggestions and guidance for enrich this write-up. I am also very thankful to Mr. Rajesh Kumar Sahu, OFS, Govt. of Odisha and Doctoral Fellow in Utkal University, Odisha for helping me in nature of translation and several time squabble-types of discussion to complete and enhance of my $\mathrm{PhD}$ work and this paper.) 


\section{Plates}

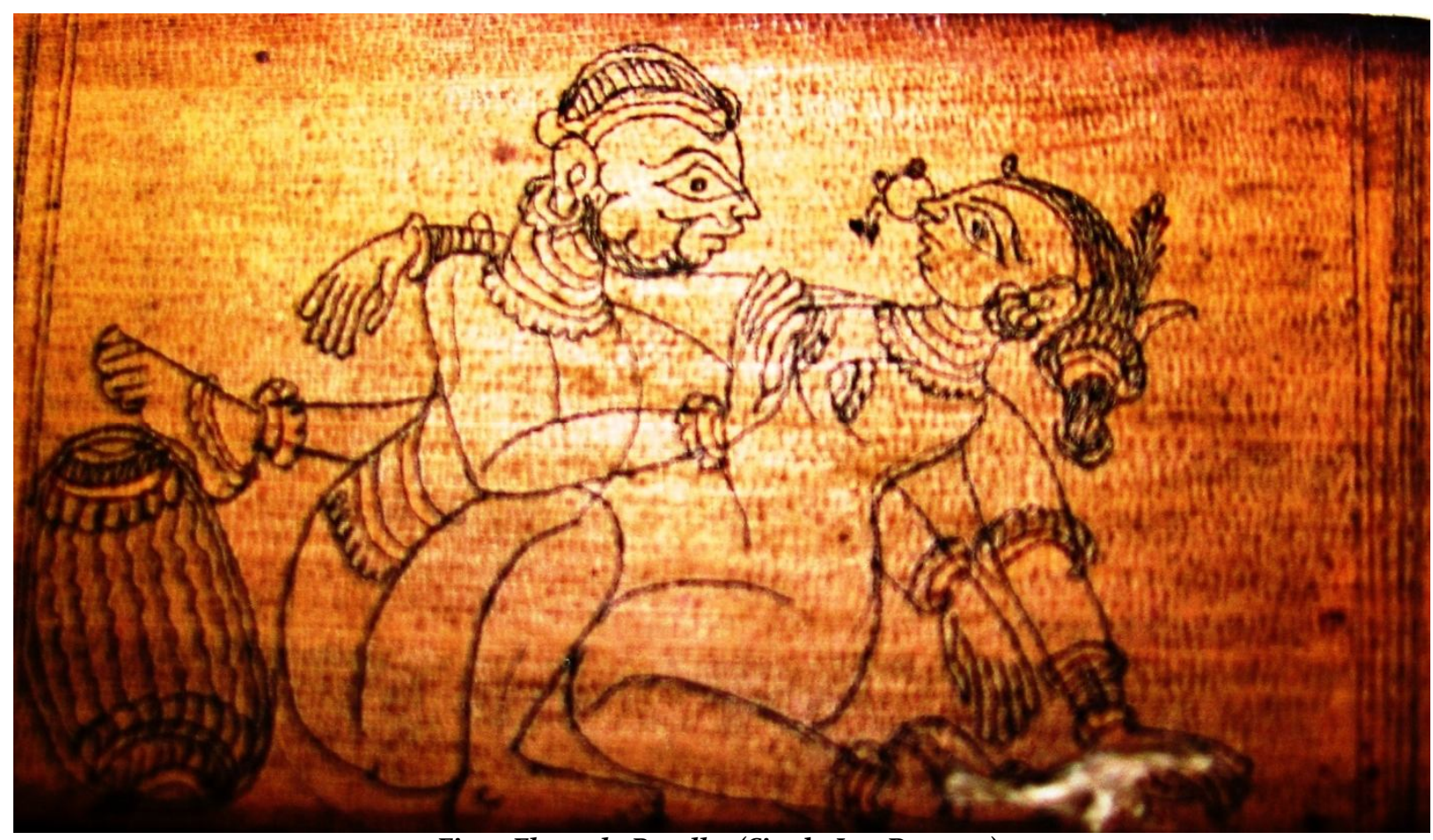

Fig.1. Ekapada Bandha (Single Leg Posture)

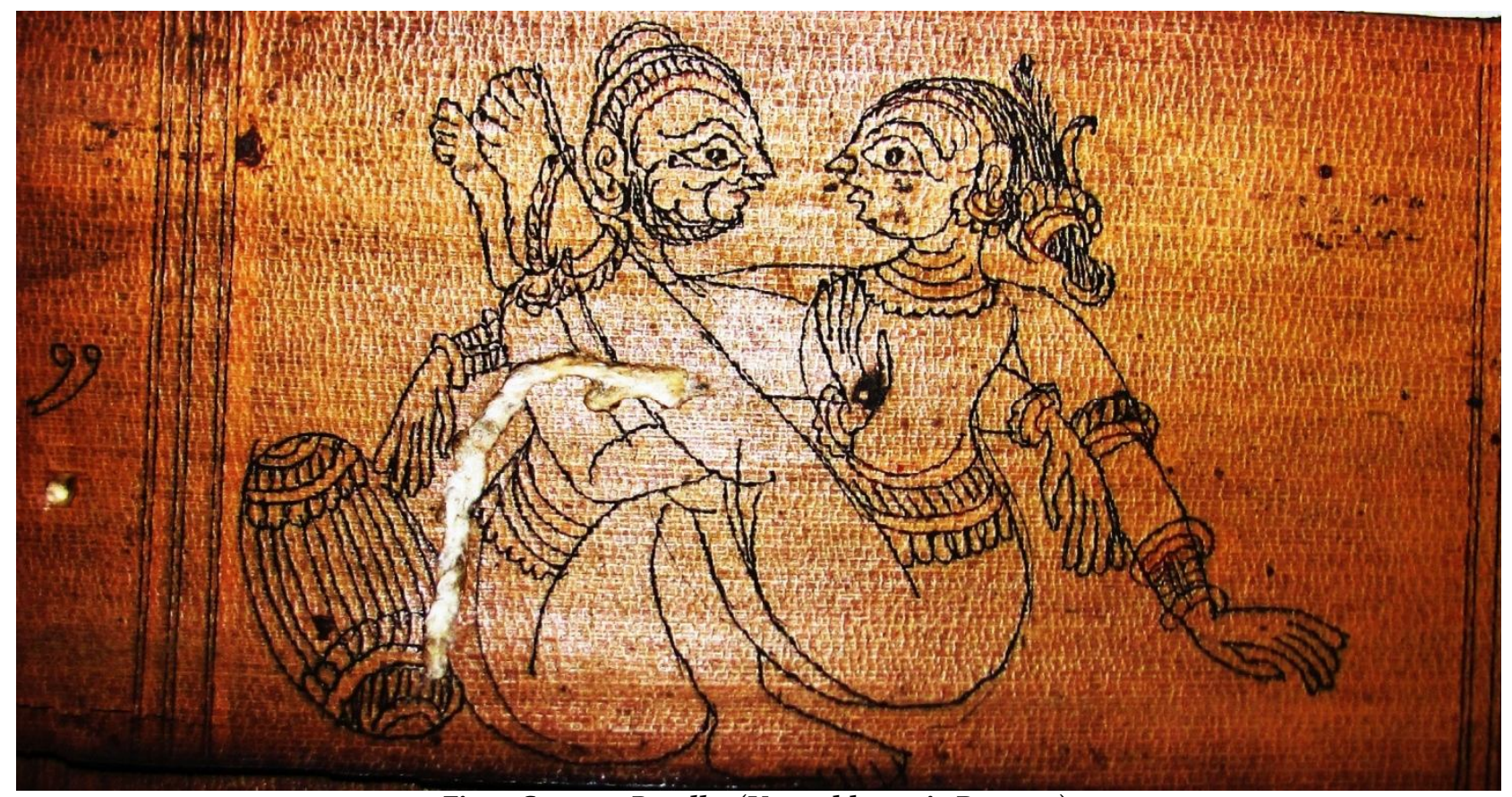

Fig.2. Susama Bandha (Unproblematic Posture) 


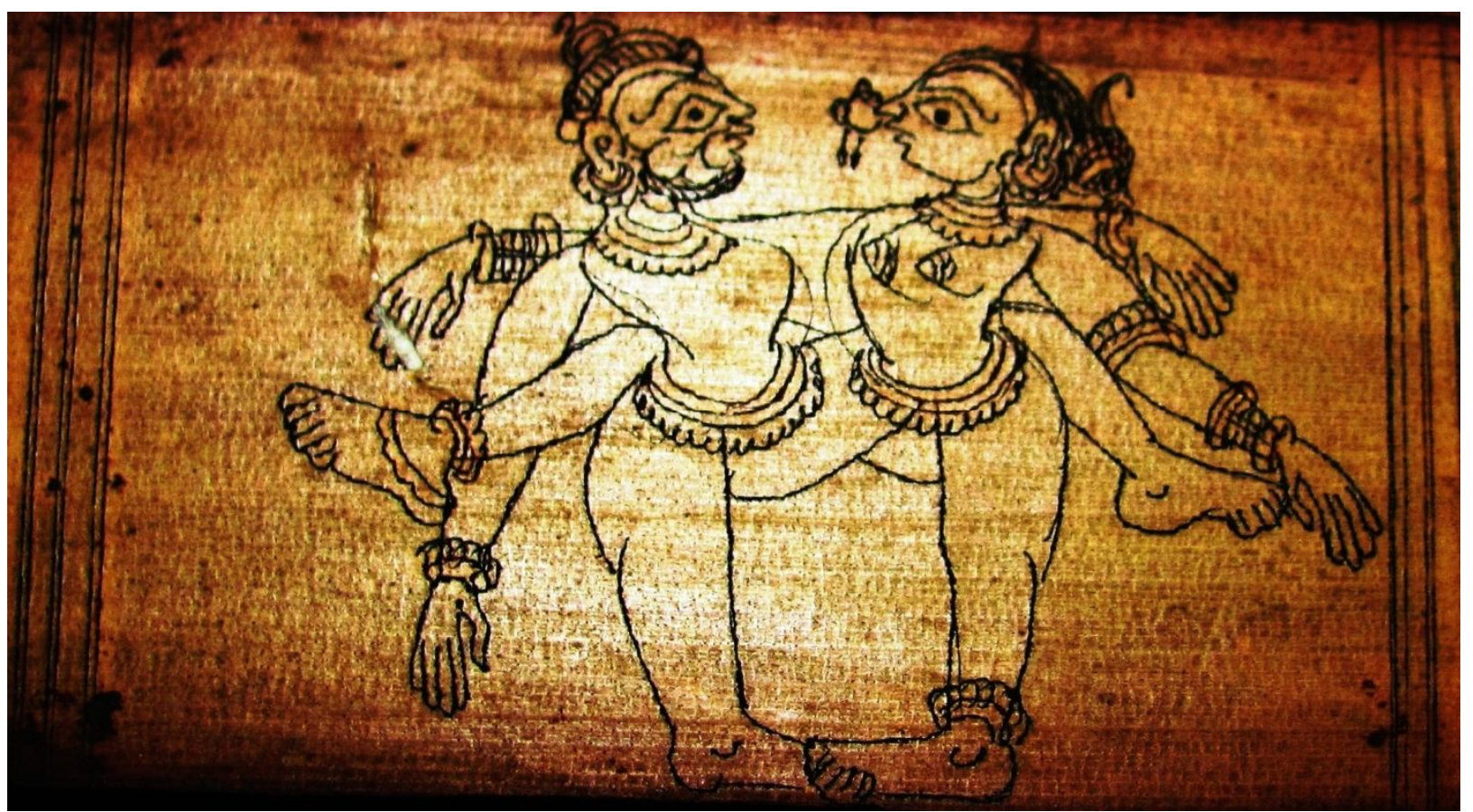

Fig.3. Karikaṇa Bandha (Anklet Posture)

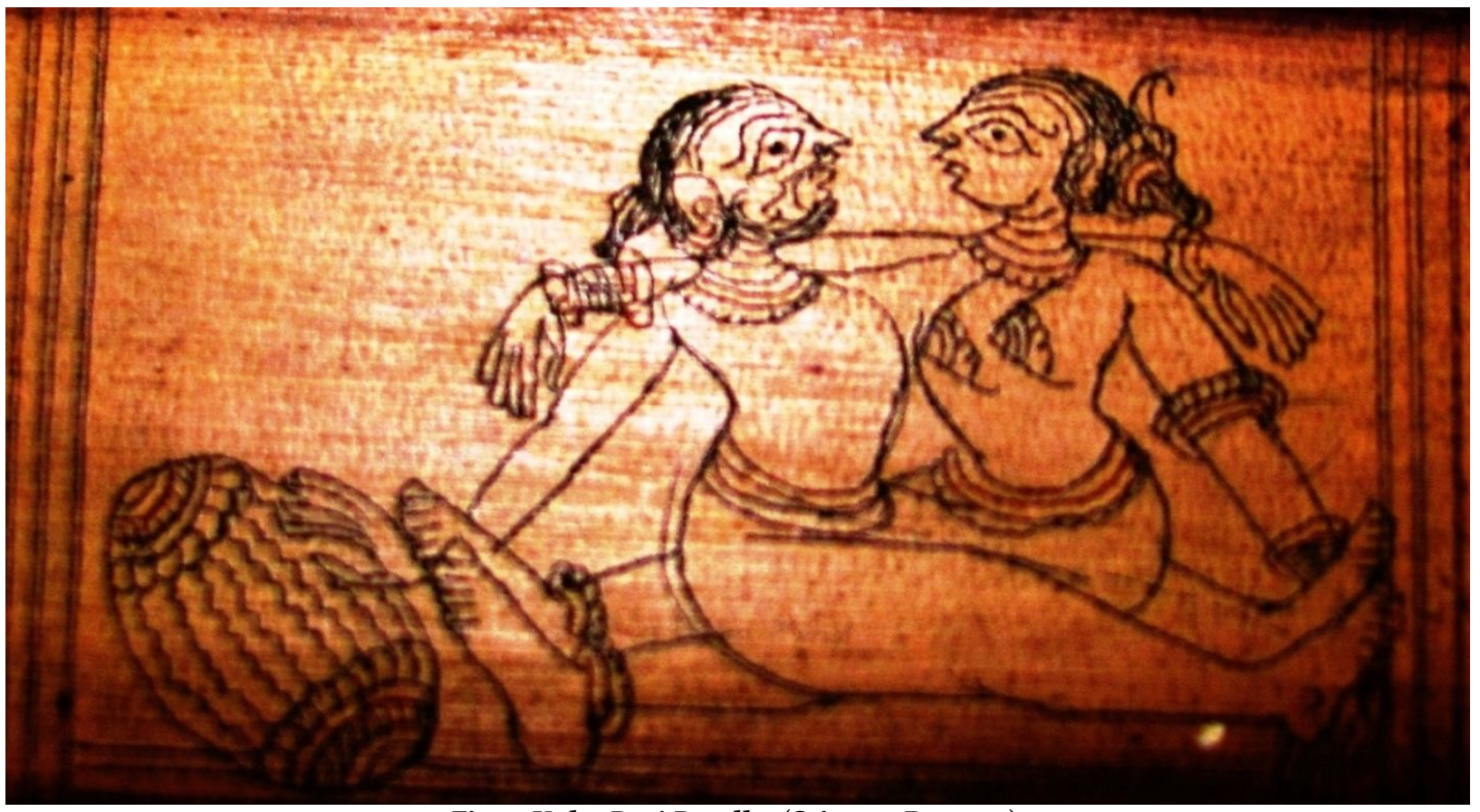

Fig.4. Käka-Rati Bandha (Scissors Posture) 


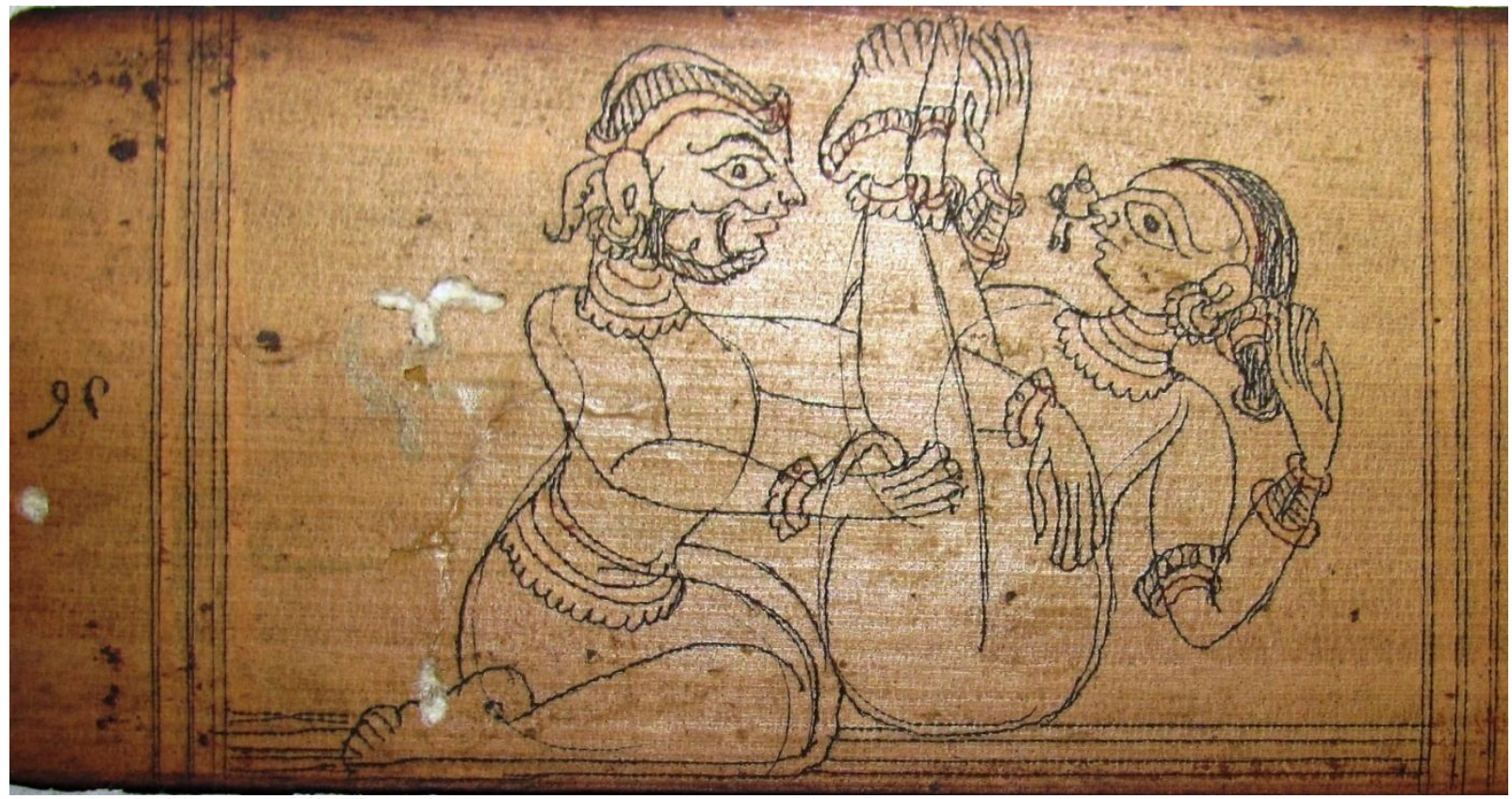

Fig.5. Urdha Pāda Bandha (Uplifting Posture)

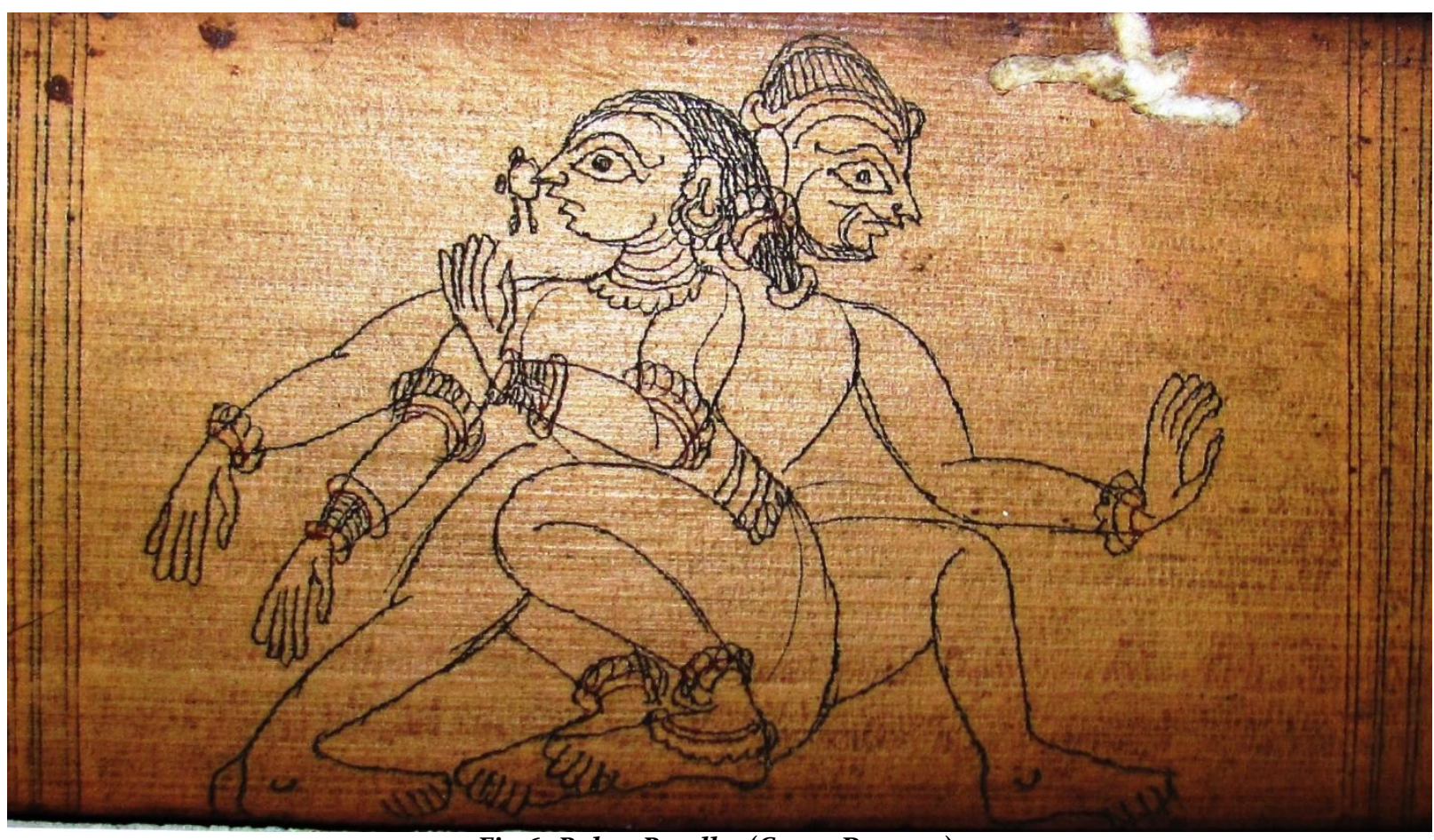

Fig.6. Bakra Bandha (Curve Posture) 


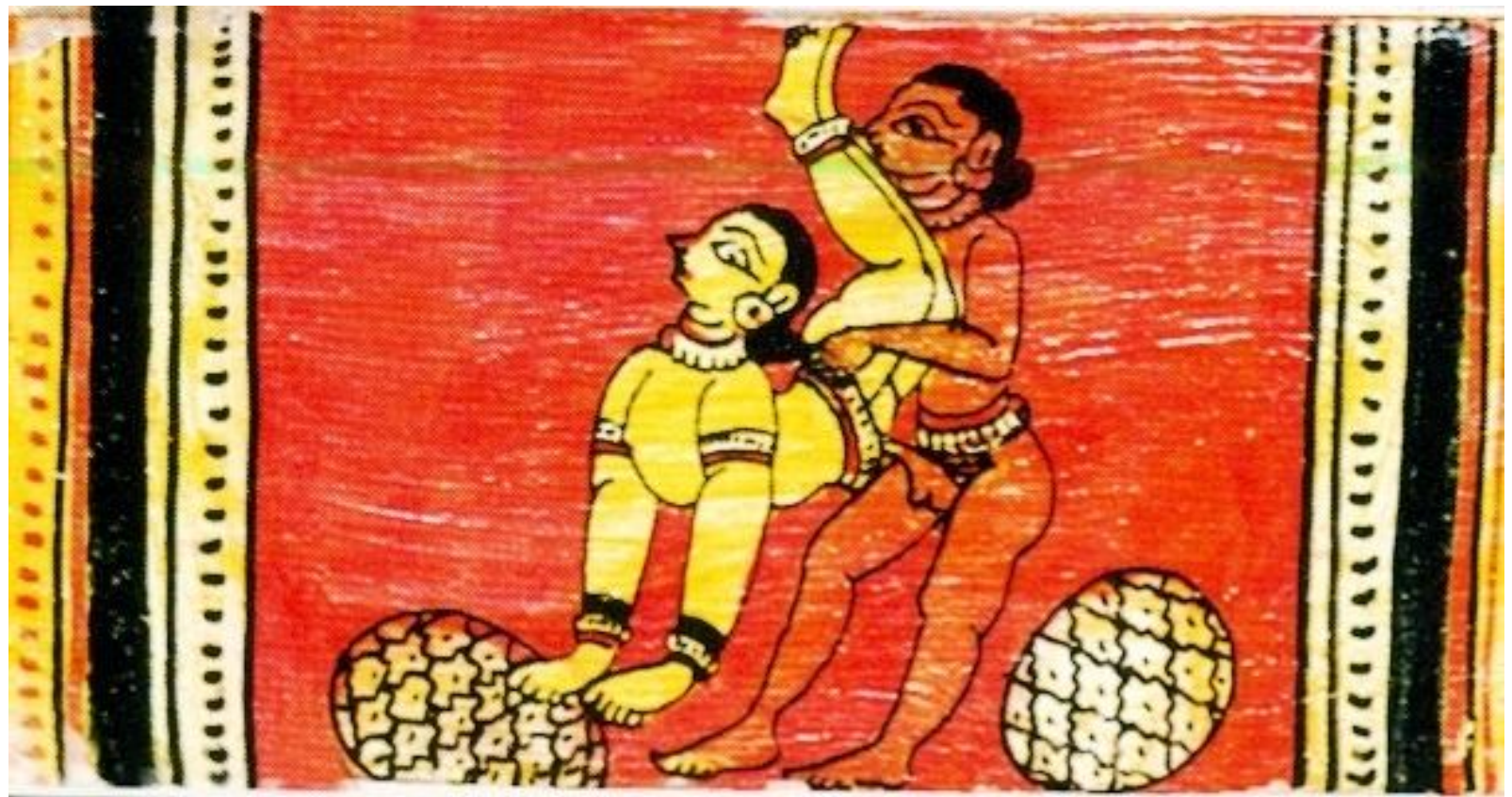

Fig.7. Mruga Matta Bandha (Standing Deer Posture)

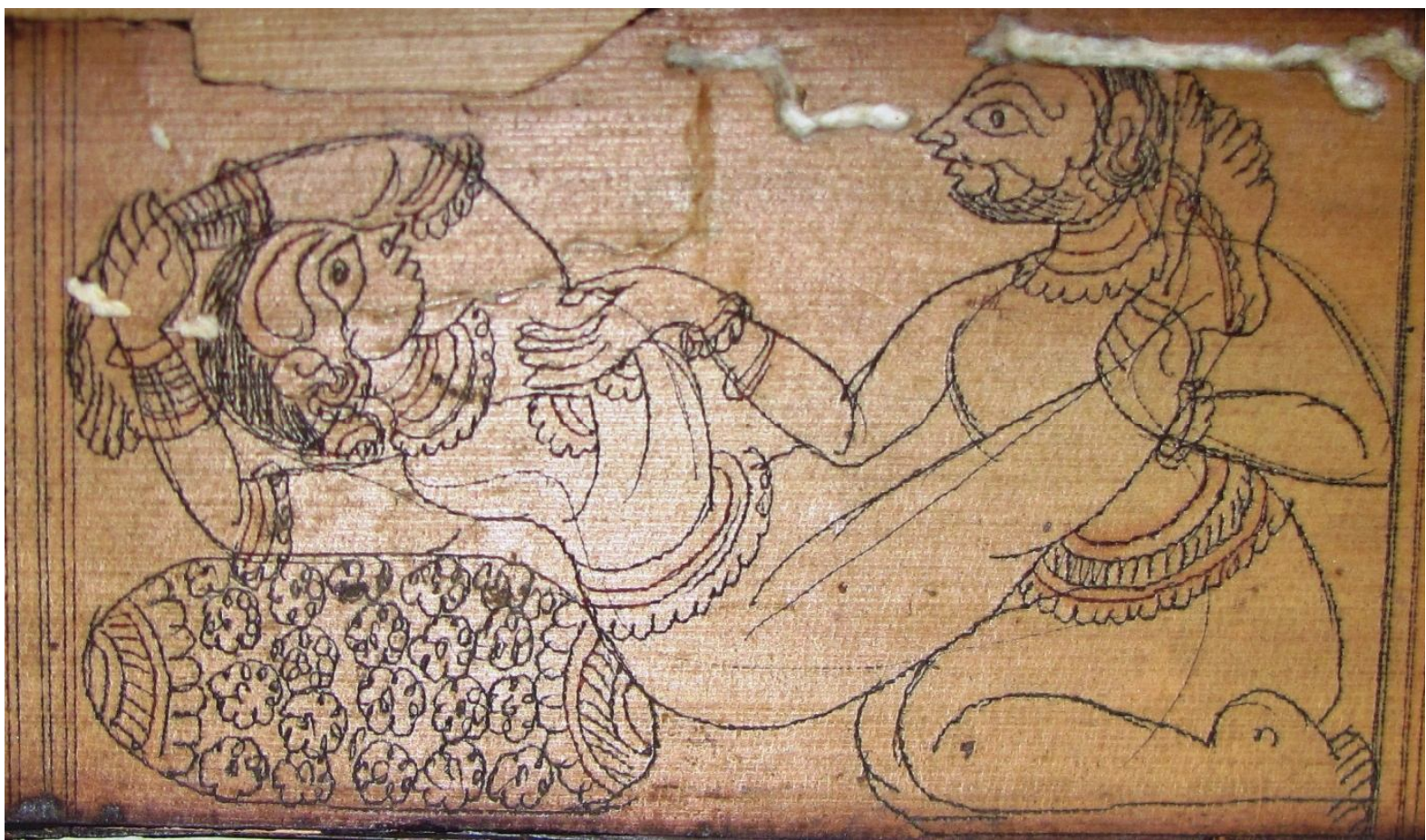

Fig.8. Rati-Bikrama Bandha (Violent Copulation) 


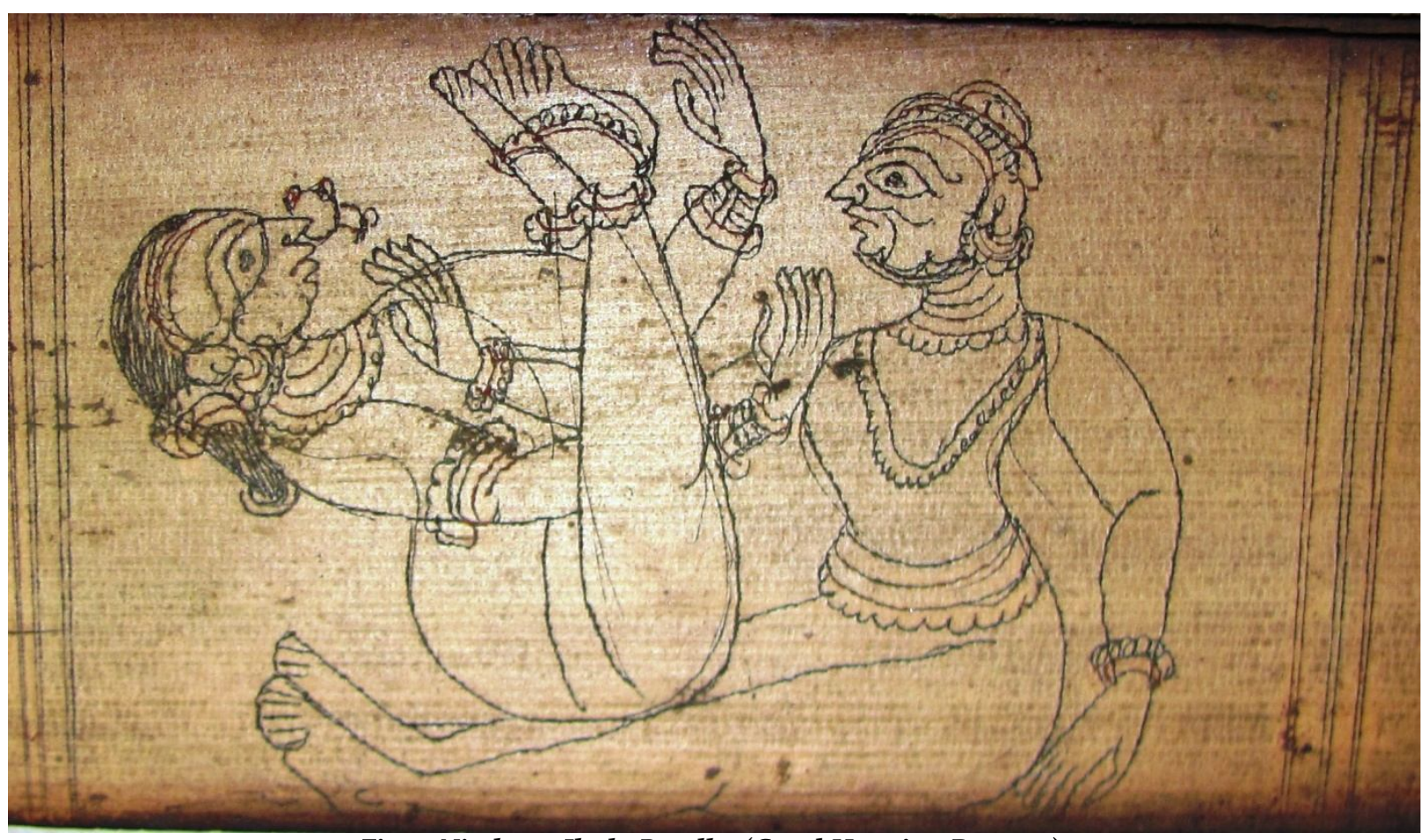

Fig.9. Nișthura-Jhulä Bandha (Cruel Hanging Posture)

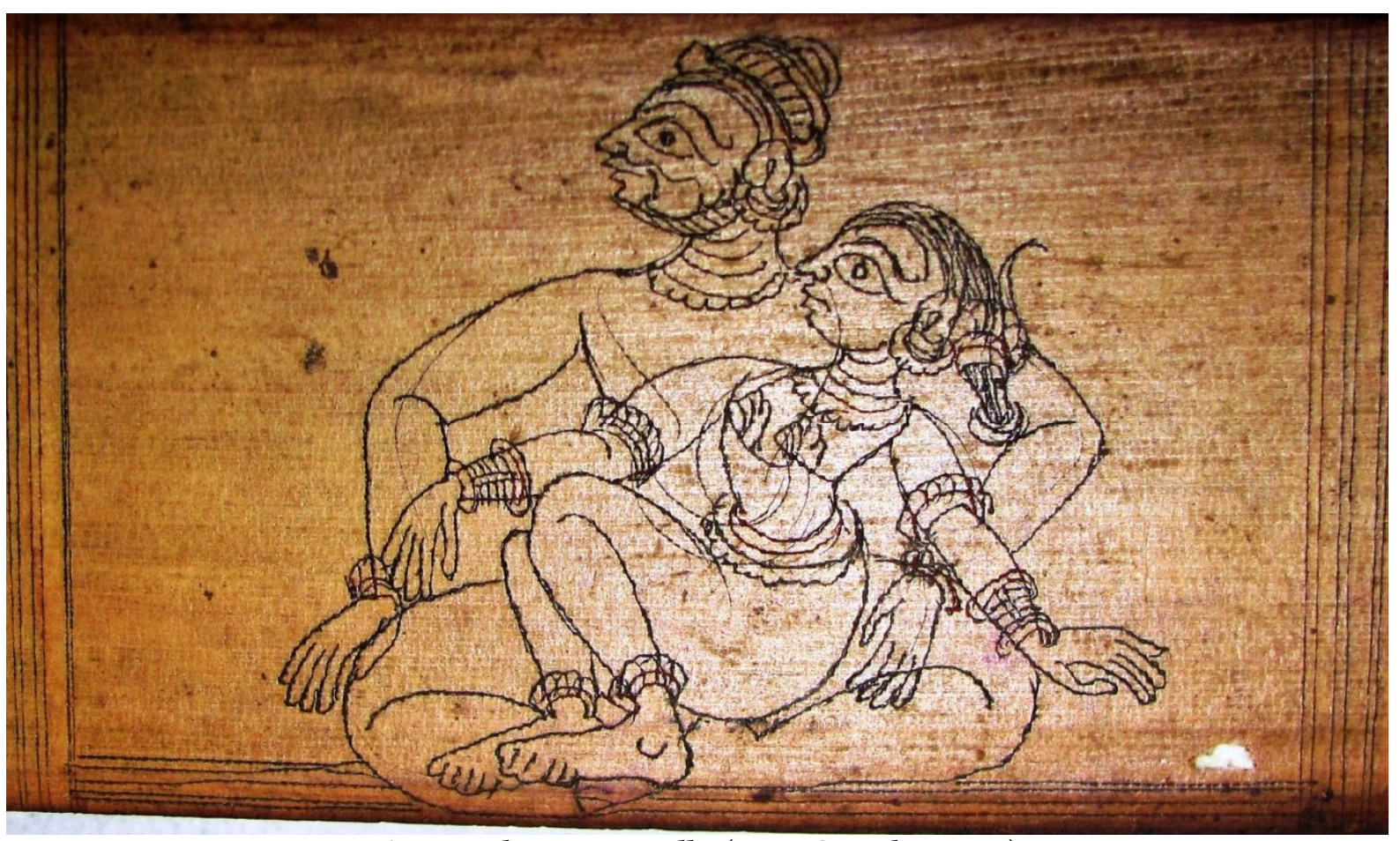

Fig.1o. Padmāsana Bandha (Lotus Seated Posture) 
187 Locating to 'Erotica' Themes in to Translation and Transcription of Palm-Leaf: Reading an Un-Known Odia 'Kāma-sūtra'

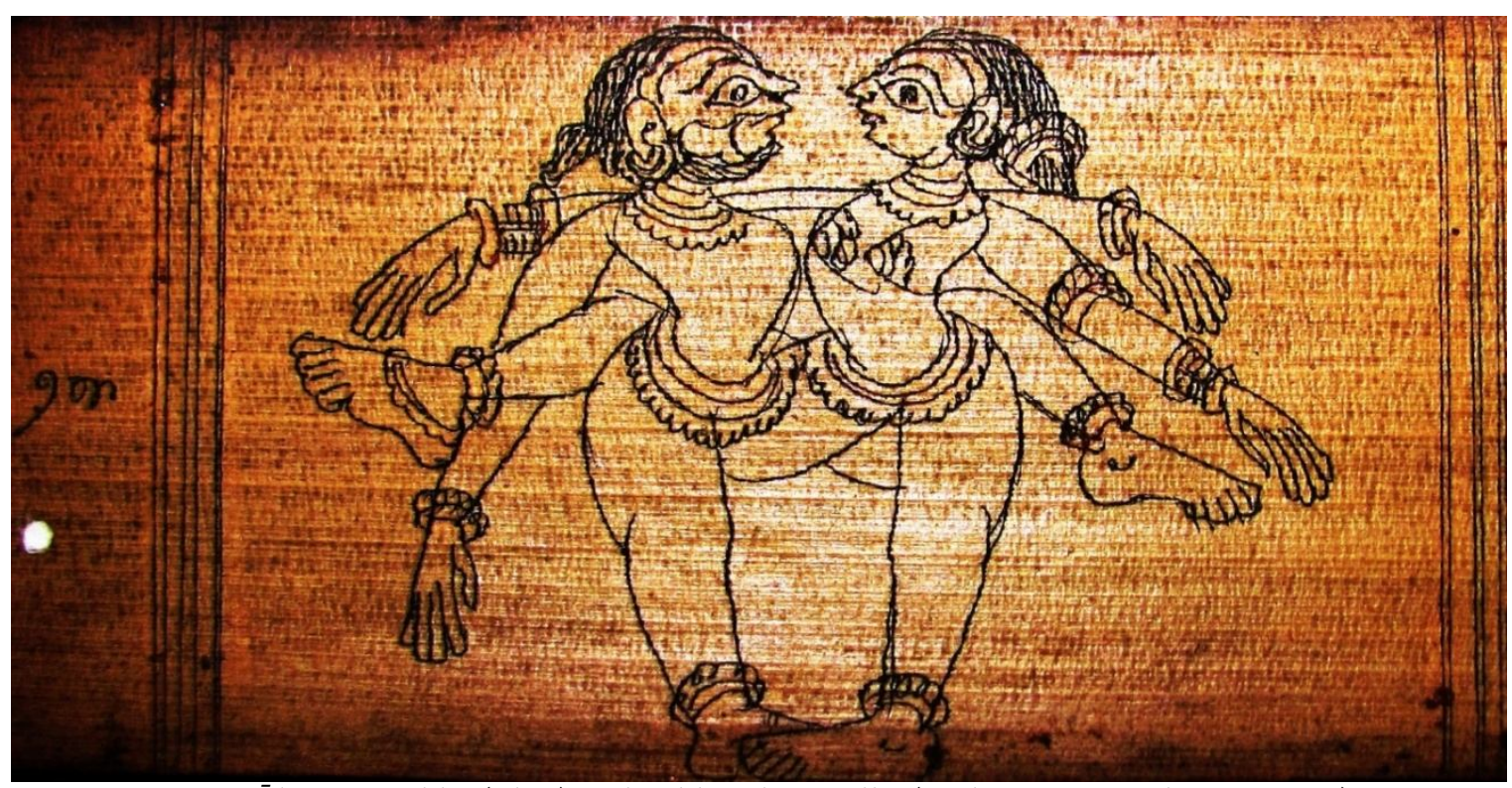

Fig.11. Ālingana Ubhāa (Thiā) Päda-chhanda Bandha (Embracing Standing Posture)

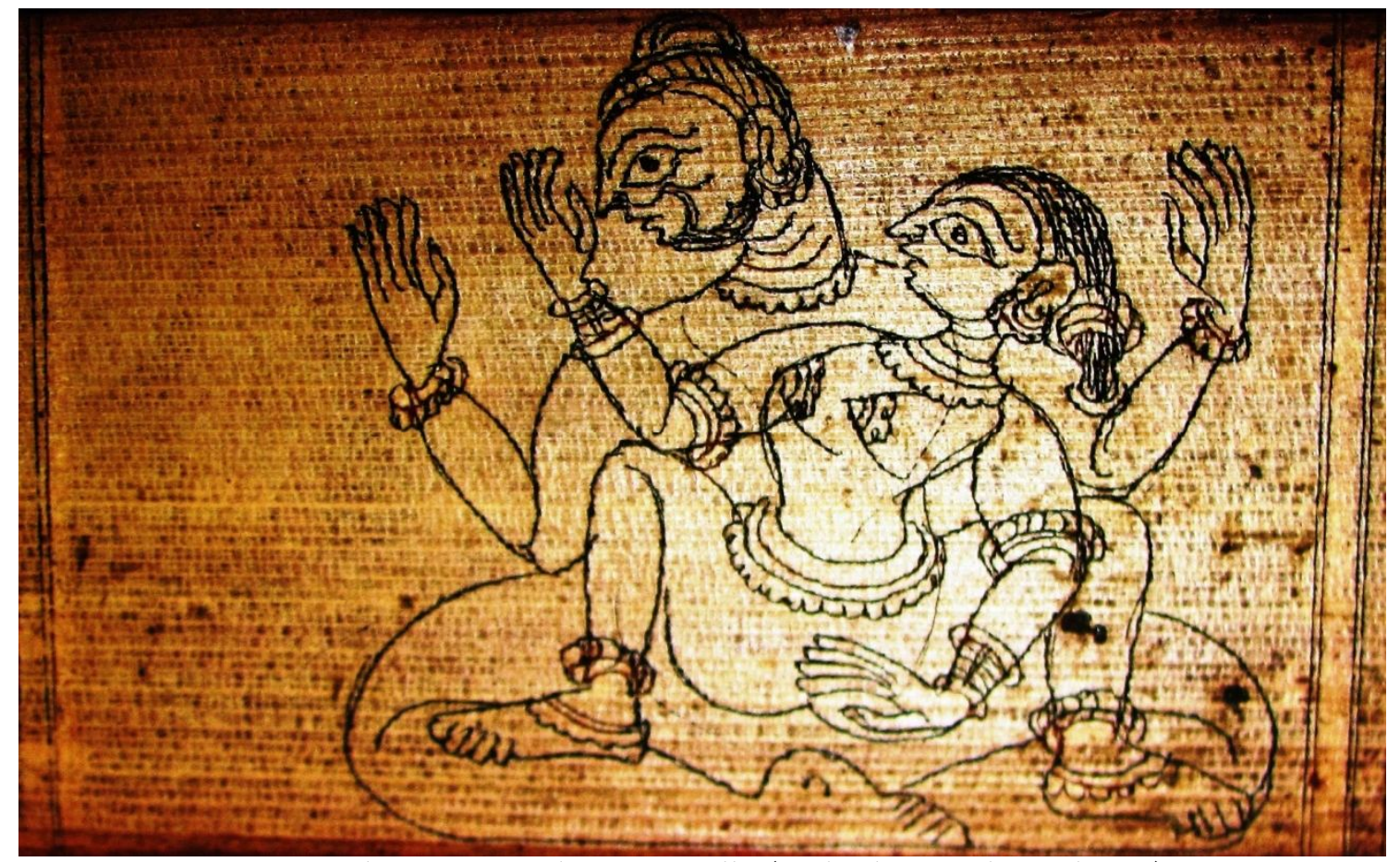

Fig. 12. Bikāra or Swastikāsana Bandha (Multiple Seated Copulation) 


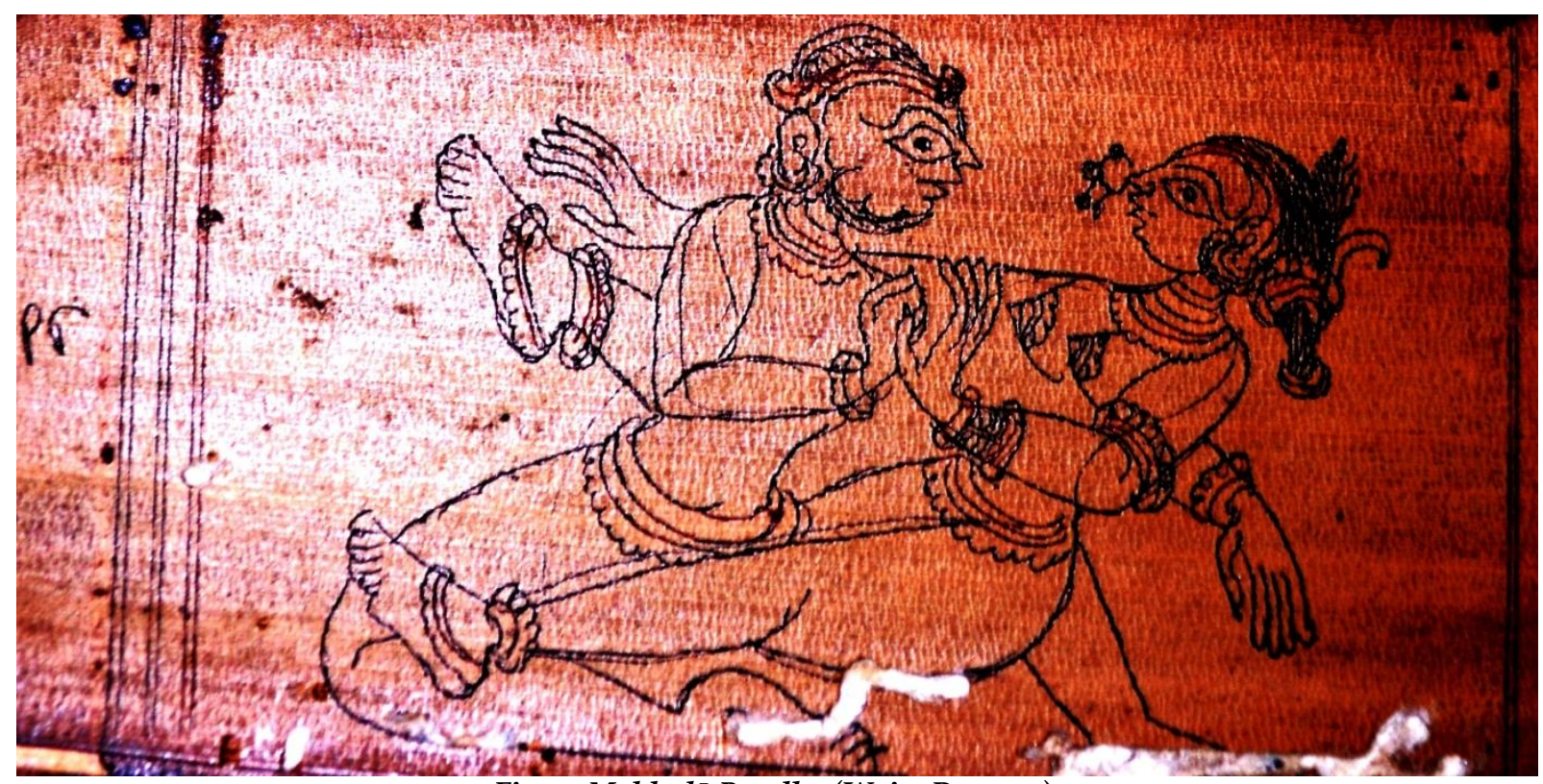

Fig.13. Mekhalā Bandha (Waist Posture)

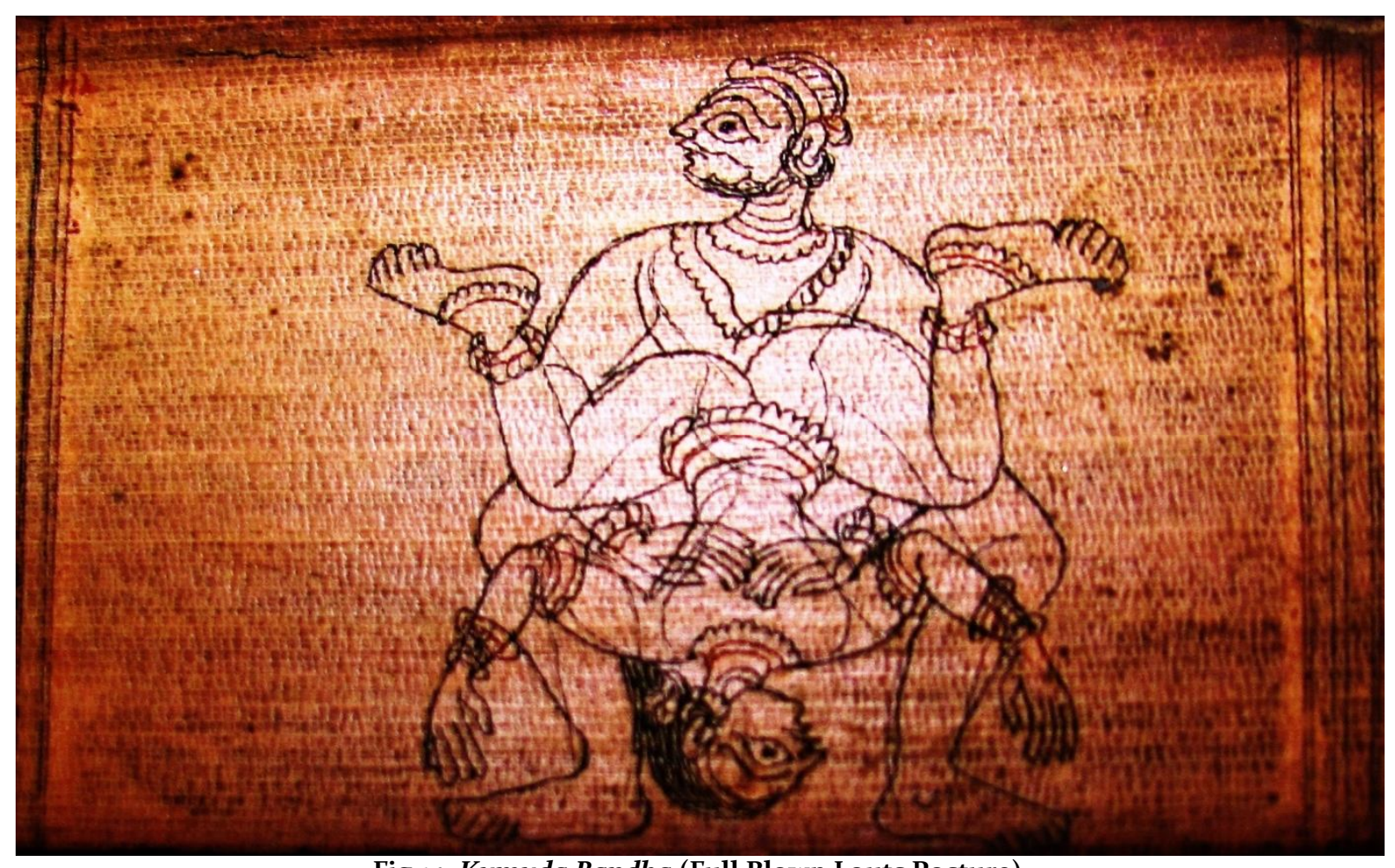

Fig.14. Kumuda Bandha (Full Blown Louts Posture) 


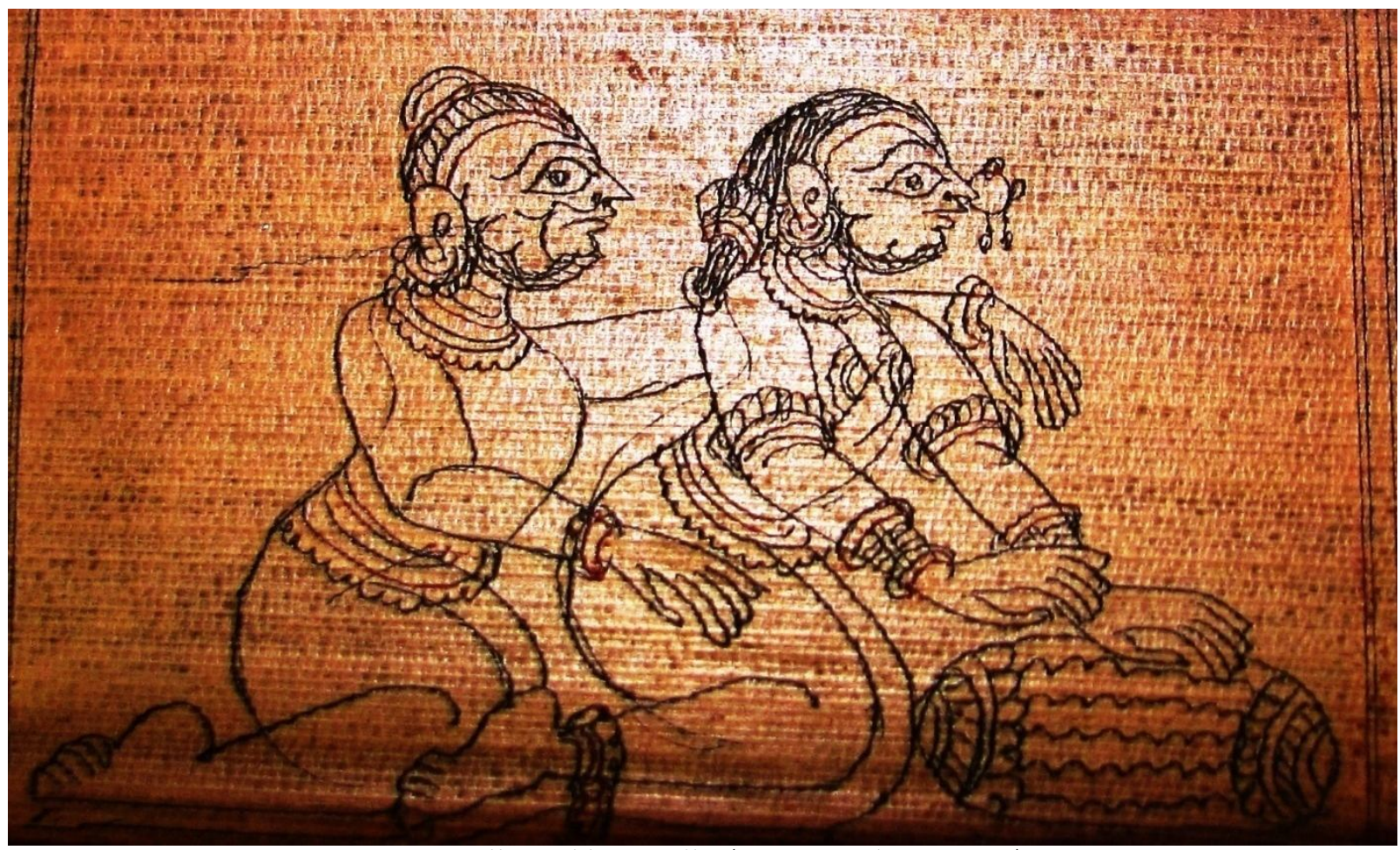

Fig.15. Adhomukha Bandha (Semi-circular Posture)

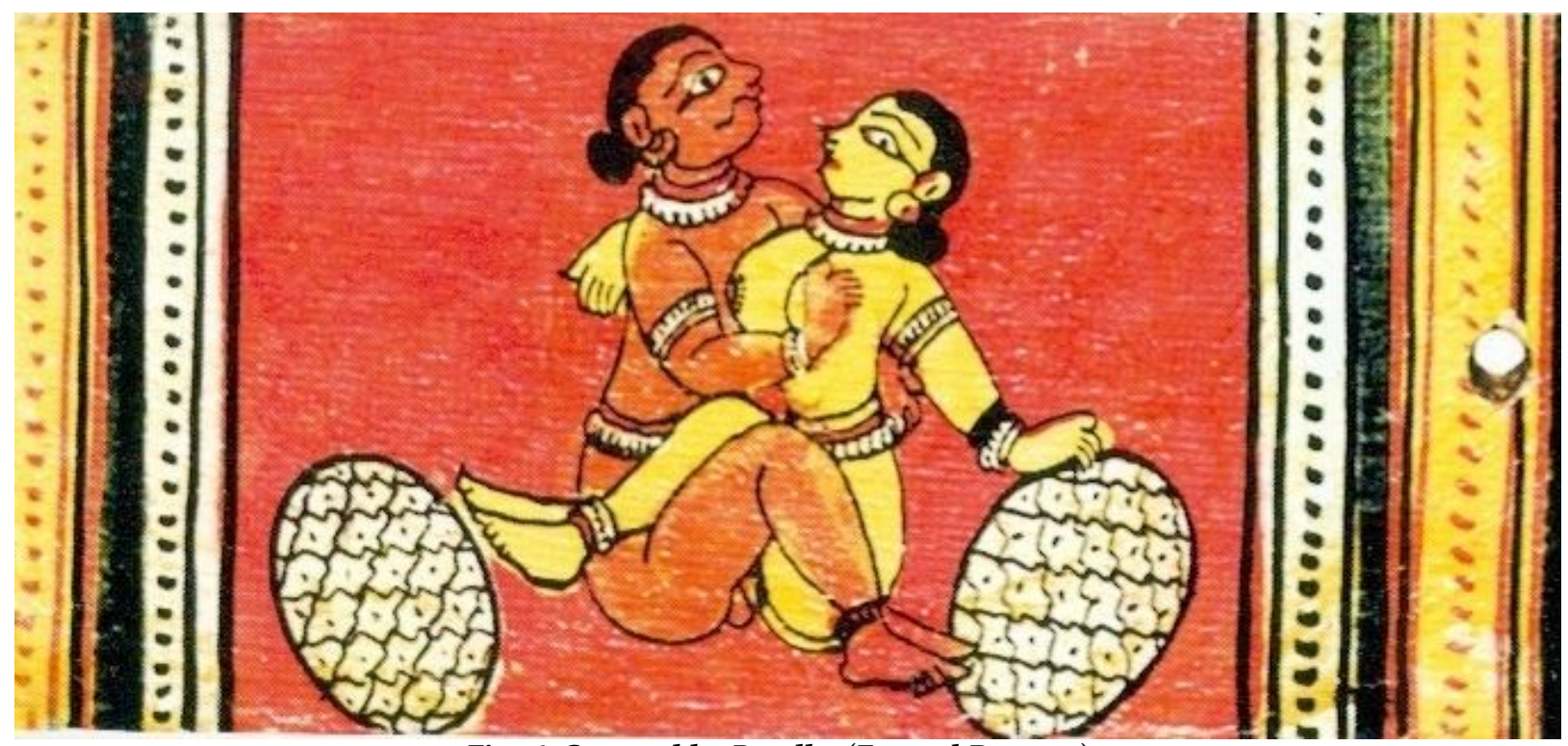

Fig.16. Sammukha Bandha (Frontal Posture) 

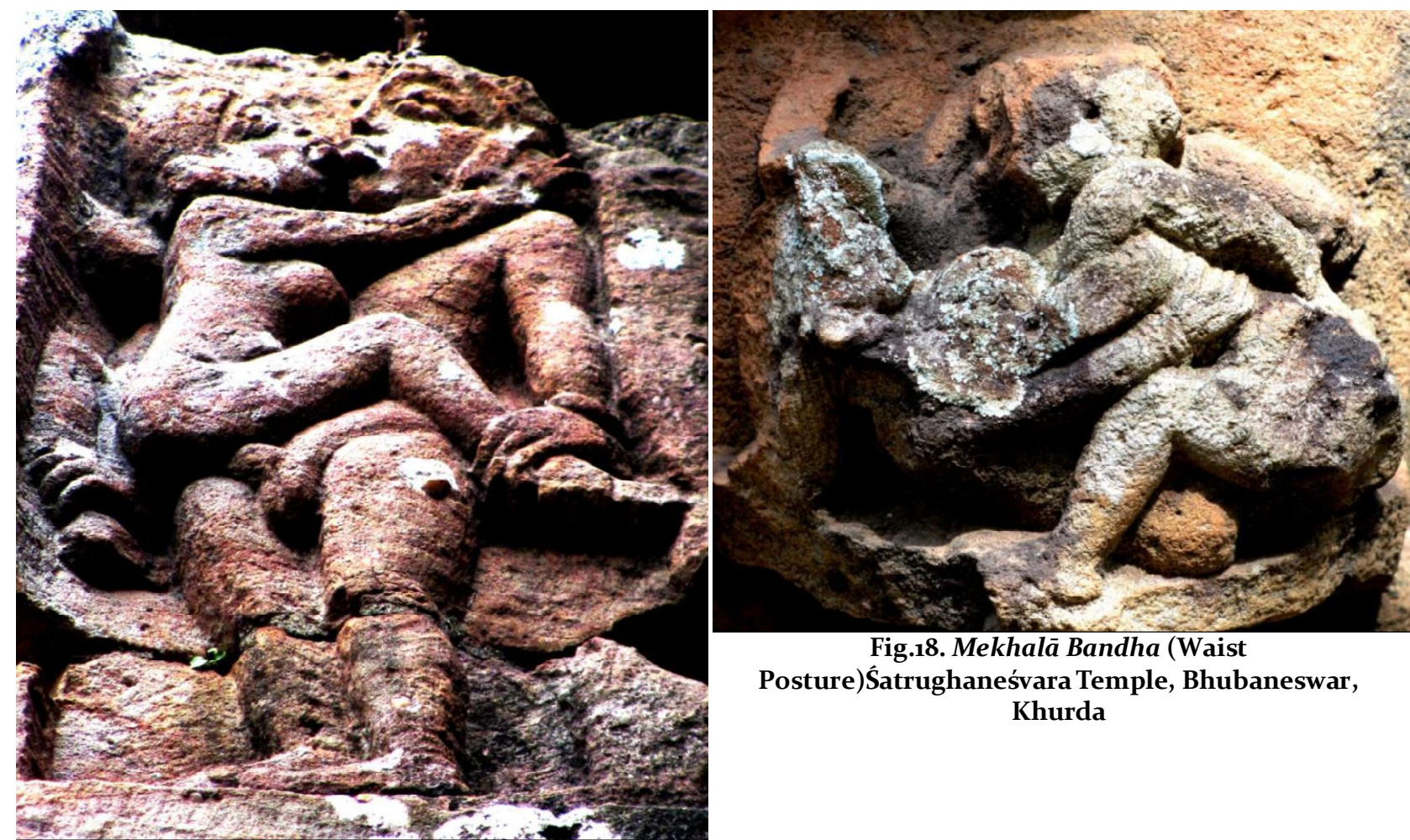

Fig.18. Mekhalä Bandha (Waist

Posture)Śatrughaneśvara Temple, Bhubaneswar, Khurda

Fig.17. Ālingana Ubhā (Thiā) Päda-chhanda Bandha

(Embracing Standing Posture), Śatrughaneśvara Temple, Bhubaneswar, Khurda

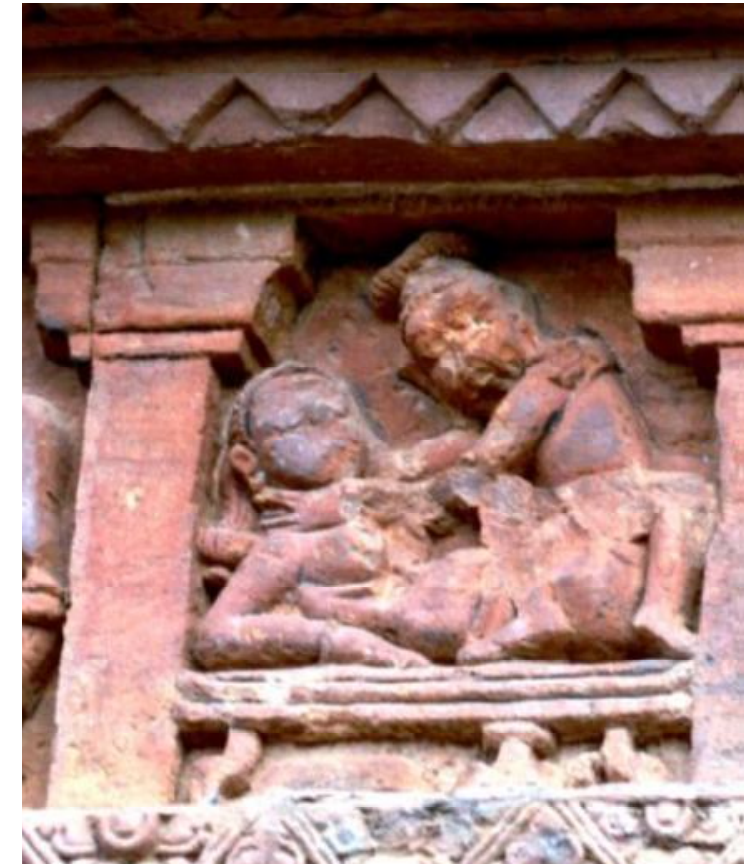

Fig.19. Rati-Bikrama Bandha (Violent Copulation, Vaitā la Temple at Bhubaneswar

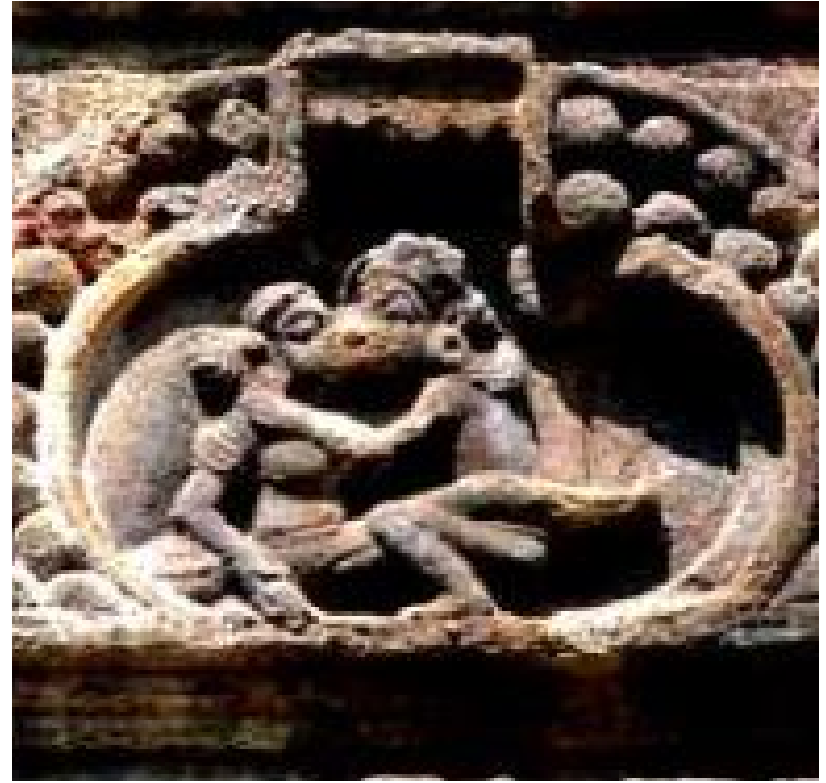

Fig.20. Kāka-Rati Bandha (Scissors Posture), Dakșhiṇeśvara /Nṛsim hanātha Temple, Badagaon, Ganjam 
191 Locating to 'Erotica' Themes in to Translation and Transcription of Palm-Leaf: Reading an Un-Known Odia 'Kāma-sūtra'

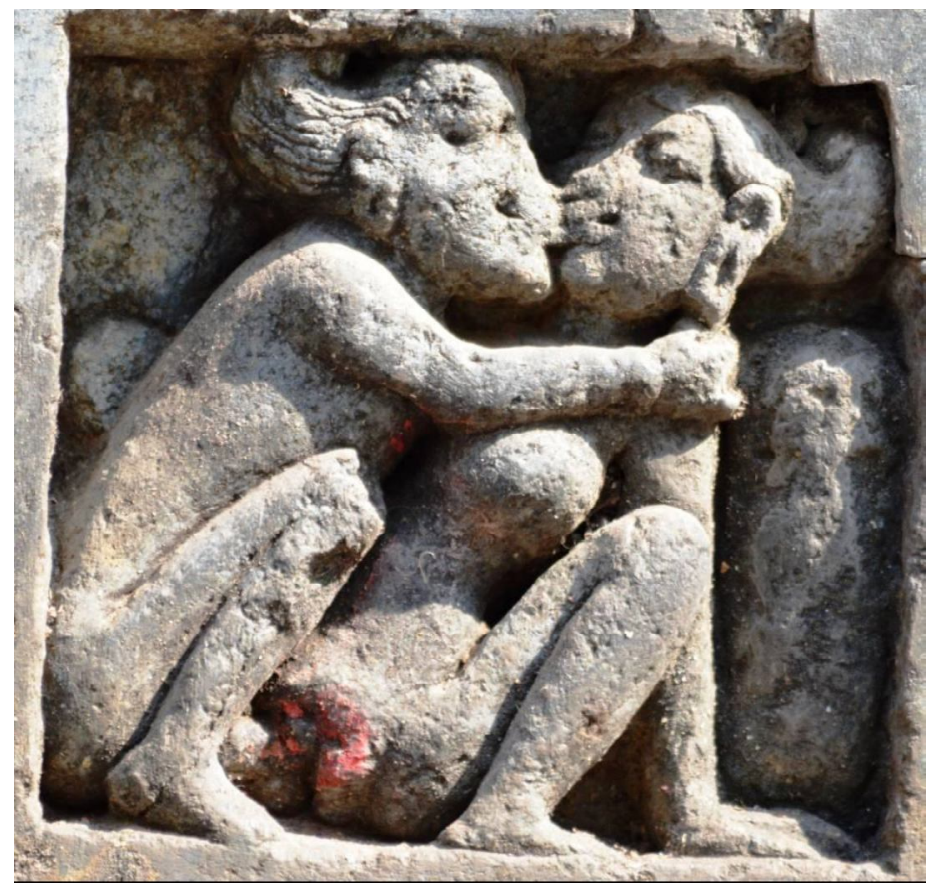

Fig.21. Sammukha Bandha (Frontal Posture), Kīchakeśvarī Temple, Khichhing, Mayurbhanj

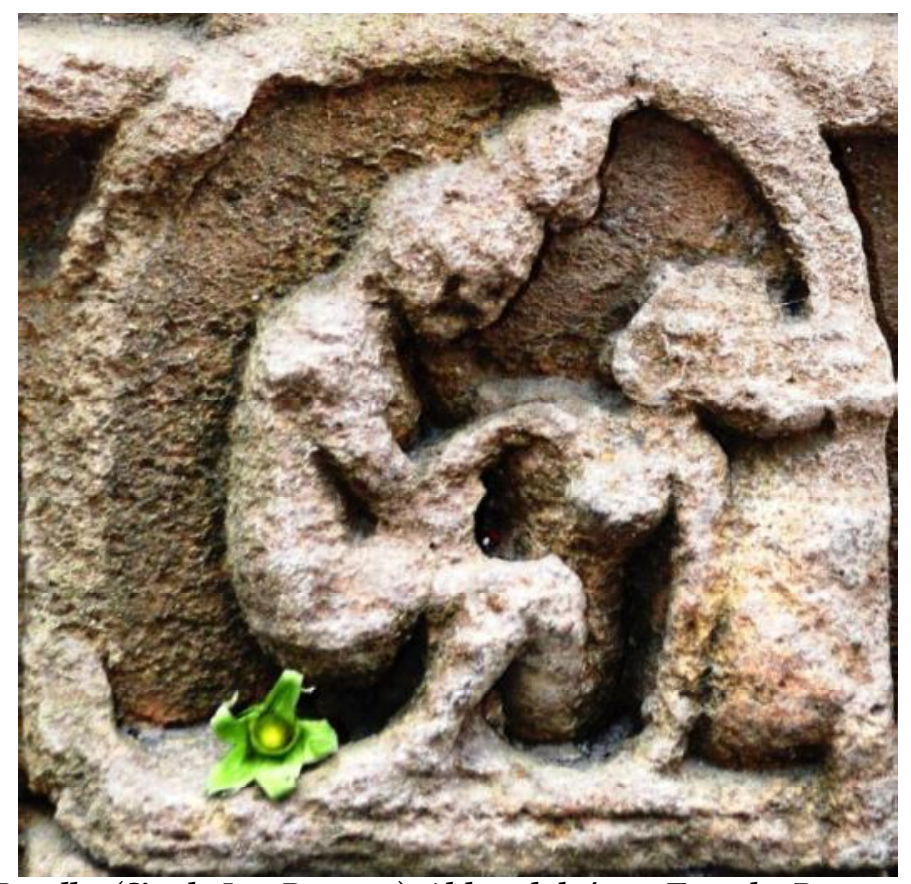

Fig.22. Ekapada Bandha (Single Leg Posture), Akhaṇḍaleśvara Temple, Prataprudrapur, Khurda 


\section{References and End-Notes:}

i. Panchanan Bhoi, The Writer and the Text: The Palm-leaf Scribe as Chronicler, Social Scientist, Vol. 33, No. 5/6 (May - Jun., 2005), pp. 73-92, and "Palm: The Sacred History Recorder", in Asian Age, $18^{\text {th }}$ February 1998, Bhubaneswar, p.9., and see also Bhoi express his ideas on Palm-leaf tradition of Odisha in his essay: "In Orissa, the palm-leaf manuscript is considered as the object of worship and the essence of the text is personified in the name of a god or goddess. Many families in Orissa keep a collection of manuscripts near the household deities and offer prayers to these. In many villages, there are libraries of manuscripts in community houses, and religious texts are read from these manuscripts at morning and evening as a daily ritual. In the social life, the art of palm-leaf inscription is used even today for recording the horoscope of newborn babies. Similarly in some areas the ceremonial invitation sent to the bridegroom from the bride's family is written on o palm-leaf. People also preserve manuscripts in their homes very carefully because they believe these as inheritance from their ancestors. The palm-leaf was considered so sacred that even after the printing press came to Orissa, important texts continued to be written on palm-leaf in preference to paper. In 1925, when a memorandum containing the demands of Odias was to be submitted to Henry Wheeler, the then Governor of Bihar and Orissa, the Oriya People's Association got it written on palm-leafs (J.P. Das, Chitra Pothi: Illustrated Palm-leaf Manuscripts from Orissa, ist ed., - Arnold-Heinemann, New Delhi-1965, pp.23-24.). So far the earliest evidence of a palm leaf manuscript dates to A.D.795, when the Chinese emperor Te-Tsang received as a token of homage an autographed manuscript of Avatamsakasutra addressed to him by king Subhakara of Wu-cha (Orissa).”...

ii . Sylvain Levi, "King Subhakara of Orissa", in E.I., Vol. XV, 1919-20, pp.263-64; and see also Panchanan Bhoi , The Writer and the Text: The Palm-leaf Scribe as Chronicler, Social Scientist, Vol. 33, No. 5/6 (May - Jun., 2005), p. 74 .

iii . The manuscript presented to the Chinese emperor contained the last section of the Avatamsaka, the section treating of the practice and the vow of the Bodhisattva Samantabhadra. Ibid; and see also Panchanan Bhoi , The Writer and the Text: The Palm-leaf Scribe as Chronicler, Social Scientist, Vol. 33, No. 5/6 (May - Jun., 2005), p. 74.

iv . M. N. Das., (ed.), Side Lights on History and, Culture of Orissa, Vidyapuri, Cuttack, 1977, pp. 663. Among these are Amaru Sataka, Bidhgadha Madhava, Geeta Govinda, Usha Vilasa, Mathura Managala, Basanta Rasa, Chitra Kavya Bandhodaya, Artatarana Chautisa, Na' Poi, Dasa Poi, Adhatama Ramayana, Bhagavad Gita Mala, Impress the onlookers.

v . The Gita Govinda (Catalogue No. Ext. /166), Odisha State Museum, Bhubaneswar, Odisha.

${ }^{\text {vi } . \text { Sishu Sankar Das's Ushavilasa, }{ }^{v i}(C a t a l o g u e ~ N o . ~ E x t . ~ / 319), ~ O d i s h a ~ S t a t e ~ M u s e u m, ~ B h u b a n e s w a r, ~ O d i s h a . ~}$

vii . Amarusatakam vii (Catalogue No. Ext. /388), Odisha State Museum, Bhubaneswar, Odisha.

viii . In the 19th Century, Narayana Das created Kumuda-kanta Chutisha, (Catalogue No. Ext. /139), Odisha State Museum, Bhubaneswar, Odisha.

ix . Rasika Harabali (Catalogue No. Ext. /40), Odisha State Museum, Bhubaneswar, Odisha.

x . Roopa Goswami's $16^{\text {th }}$ Century classic, Bidagdha Madhava, (Catalogue No. Ext. /310) is literally a drama of the agony and ecstasy of the jugalbandi of Krishna and Radha, the symbolic union of Purusa and Prakriti. Pournarnasi plays the bridge. However it differs in many ways from the theme of the narrative framework of the more famous Gita Govinda notably by the introduction of characters representing the moral impediments to the union of Radha and Krishna. Bidagdha Madhava is completely Krishnas love story with Radha \& other Gopis. The names of Krishna, Radha, Pouranarnasi, Visakha, Lalita etc are mentioned in the manuscript.

xi . Details Translation work will Un-published PhD Thesis of the present writer. .

xii . Ibid., 
xiii. Binode Routray., Traditions in Paintings, in "Art Traditions of Orissa”, (Ed.) Odisha Sahitya Akademi, Bhubaneswar, p. 62, pp. 55-69.

xiv . Mayadhar Mansinha., A History of Oriya Literature, Sahitya Akademi, New Delhi, 1962, $2{ }^{\text {nd }}$ Edition 2005, p. 108, and see also Mayadhar Mansinha, Odia Sahityara Itihasa, Cuttack, 1967, p. 132.

${ }^{x v}$. Ibid., p. 109., op.cit., Odia Sahityara Itihasa, p. 133. The meaning of Chautisha is a literary creation created by using thirty four consonants of Odia letter, starting from ' $K a$ ' to ' $K s ̦ h$ '. It took all types of subject matter within its ken. These include prayer, devotion, separation and union of love, sorrow full emotion etc.

xvi . Ibid.,

xvii . Ibid.,

xviii . Ibid.,

xix . Ibid.,

${ }^{x x}$. Ibdid, op. cit., p. 133.

xxi . Op. cit., p. 133.

xxii . Ibid.,

xxiii . Ibid., pp. 133.

xxiv . Ibid., p. 133.

xxv . Ibid.,

xxvi . Mayadhar Mansinha., A History of Oriya Literature, Sahitya Akademi, New Delhi, 1962, $2^{\text {nd }}$ Edition 2005, p. 85, and see also Mayadhar Mansinha., Odia Sahityara Itihasa, Cuttack, 1967, p. 101., see also pp. 8485.

xxvii . Ibid., see also pp. 84-85.

xxviii . Jagannath Prasda Das., Desha, Kala, Patra, “Cuttack: March 1894", Friends Publisher, Cuttack, pp. 414419, and see also English translation “A Times Elsewhere," Penguin Book, New Delhi, 2009, pp. 369-375. "The Radhanataha Ray's work has been considering civility and Upendra Bhanjas work as consider coarse or vulgar. After the introduction of printing press in Odisha and advent of Odia Nationalism; at that time the 'Bijuli' (September, 1893) and 'Indradhanu' (August 1893) play the role in the writings of the Radhnatah Ray and Upendra Bhanja as the simple point is respectively civility and vulgar." 